\title{
The Middle Kingdom Seated Royal Statues Reused By King Ramses II
}

\section{ReHAB ELShaRnOUby \\ FACUlty Of TOURISM ANd Hotels, Mansoura UnIVERsity, Egypt}

\begin{abstract}
Ancient Egyptian Statuary offers great information and insights into the art and history in those glorious times. It provides valuable, detailed and in-depth understanding into the artistic features, characteristics and physiognomies of the various eras and king reigns. Additionally, reprocessed statuary in different ancient periods accumulates more knowledge and intuitions about ancient Egyptian art. Those comparative analysis, and contrasts between different styles and adaptations enrich correlations and cross effects among different ancient periods. It is worth mentioning that the majority of reused statues are royal, but the discovered reused private ones are limited in number.

This research focuses on the Middle Kingdom seated royal statues that have been sculpted during the Middle Kingdom and were later reused by King Ramses II (XIX Dynasty).

The first part of the study gives a full description of these statues: The material, provenance, present location, characteristics and the inscriptions carved on the statues. They are classified as follows: Group seated statues and single seated statues. The second part of the research gives a full analysis of each statue criteria in order to assign it to its original owners. Finally, it ends by a conclusion that reiterates the most important results of the current study.
\end{abstract}

KeYwords: Statues, Seated, Museum, King, Ramses II, Throne, Table.

\section{INTRODUCTION}

Ancient Egyptian Statuary offers great information and insights into the art and history in those glorious times. It provides valuable, detailed and in-depth understanding into the artistic features, 
characteristics and physiognomies of the various eras and king reigns. Additionally, reprocessed statuary in different ancient periods accumulates more knowledge and intuitions about ancient Egyptian art. Those comparative analysis, and contrasts between different styles and adaptations enrich correlations and cross effects among different ancient periods. It is worth mentioning that the majority of reused statues are royal, but the discovered reused private ones are limited in number.

This research focuses on the Middle Kingdom seated royal statues that have been sculpted during the Middle Kingdom and were later reused by King Ramses II (XIX Dynasty). The researcher seeks to gather all the appropriate information about these statues, in order to determine the statues original owners, and attribute them to those owners. Additionally, not all the studies that discussed this subject included translations of the texts and some of those translations are the researcher's work. Note that the dating of those statues is specified according to the actual inscriptions engraved on those statues, not the original date, which they were sculpted. Finally, the statues in the first part are ordered chronologically.

\section{Group Seated Statues}

\section{Statue 1: A Seated Dyad of a King ANd a Goddess (Pl. 1)}

This red granite dyad of a king and a goddess was found in Goddess Wadjet temple in Buto. It is still in Situ. ${ }^{1}$ It depicts King Ramses II (originally King Amenemhat I, XII Dynasty) and most probably Goddess Wadjet, the Mistress of Buto. Both figures are represented sitting next to each other on a rectangular low backrest throne with no back slab. This is a characteristic feature of the dyads of the Middle Kingdom. Both throne sides are ornamented with the Lotus and Papyrus knotted together (symbols of Upper and Lower Egypt) in sunken relief, composing the sm3 t3wy sign, "The union of the Two Lands". The king is wearing the royal nemes, the royal pleated šndyt kilt, but his face is eroded. Although the face of the goddess is damaged and her name is lost, but her cosmetic lines, cheeks and ears still exist. She is portrayed in a complete female figure: Wearing a

\footnotetext{
${ }^{1}$ Buto, in Egyptian $\square$, $\mathrm{B} p r$ - $W 3 \underline{d} t$, "The house of Wadjet", in Arabic Tel Elfaraana. It is one of Dessouk villages-Kafr Elsheikh Governorate. It was the cult center of Goddess Wadjet and the capital of Lower Egypt before the unification. . Tr
}

$$
\text { ؛ عبد الحليم نور الدين، مواقع و متاحف الآثار المصرية (القاهرة، ه. . ب). }
$$


tripartite wig with vertical strains, a large beaded wsh collar and a tight ankle-length garment. The king embraces the goddess waist with his forearm, while the right arm of the goddess is put on the king's back. The right hand of the king and the left hand of the goddess are resting flat on their knees. The couple almost has the same facial characteristics such as full cheeks and small structured ears.

The cartouches, bearing the name of King Ramses II, are inscribed on the throne backward and are flanked by two serekh. Both serekh are damaged except a part from the left one and it can be read as follows: mry M3 ${ }^{\top} t$, "Beloved of Goddess Maât". The two cartouches are partly damaged, from right to left, they can be read: (wsr-m3`t-R $\left.{ }^{\top}\right) s t p-n-R^{c}$ (mry-Imn R`)-msw (Fig. 1). ${ }^{2}$

\section{Statue 2: A Seated Triad of a King and the Two GODDESSES ISIS AND HATHOR (PL. 2)}

This life-sized dark brown-red granite triad, which measures $1.74 \mathrm{~m}$ height ${ }^{3}$ was found on the northern steps leading to the Ptolemaïc temple in Koptos. ${ }^{4}$ It is now exhibited in the Egyptian Museum in Cairo under number CG 555. ${ }^{5}$ The group statues represent King Ramses II (originally King Senousert I, XII Dynasty), sitting between Goddesses Isis to his right and Hathor to his left on a joint throne. The king's nose and mouth are damaged. He is wearing a plain nemes with little visible horizontal lines and the uraeus is lost. His small ears, with pierced ear-laps, are exposed from the nemes. The king large semi-circular eyes are sculpted with straight lower rims. There are two folds on his neck. His nipples are drawn in relief within an incised circle. His two hands are resting flat on the knees while his legs are adjacent to each other leaving no place for the tail

${ }^{2}$ F. El Mekkawi, "Recent Excavations at Tell el Fara", $D E$, Special Number 1 (Cairo, 1989), 204-205; H. Sourouzian, "Features of Early Twelfth Dynasty Royal Sculpture", Bulletin of the Egyptian Museum, 2 (Cairo, 2005), 106-107, pl. VI a-b.

${ }^{3} P M V, 125$.

${ }^{4}$ The word Koptos derives from the Egyptian name 8 gbtyw, in Arabic Quaft. It is located $25 \mathrm{~km}$ south east Dendara-Qena Governorate. It was the center of Min cult, the god of fertility.

${ }^{5} \mathrm{PM} \mathrm{V}, 125$.

$$
\text { ؛ عبد الحليم نور الدين، متاحف الآثار ، YV }
$$


of the bull. The two goddesses are wearing tripartite wigs without emblems and tight ankle-length garments with ornamental ribbons beneath their breasts. Their necks are engraved by two folds; their ear-laps are pierced; their hands are positioned flat on their knees, holding in their right hands the sign of $f$ e $n h$. The statues are propped by a large high backrest, while putting their bare feet on a rectangular pedestal. ${ }^{(6)}$

The triad is inscribed with King Ramses II name. Two vertical cartouches, indicating his coronation name, are flanking the king's

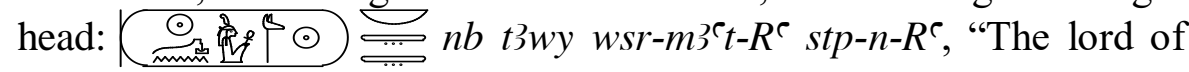
the two lands, wsr-m3 't-R $R^{e}$ stp-n-R". Another two vertical cartouches, depicting his birth name, are flanking his legs:

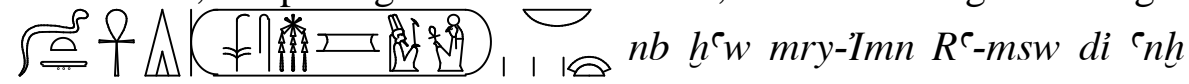
$\underline{d} t$, "The lord of appearance, mry-Imn $R^{\mathrm{e}}-m s w$, given life eternally".

Six vertical columns are engraved on the back pillar; the three columns from the right are facing right, while the other three from the left are facing left. Goddess Isis text can be read from right to left as follows: $d d m d w$ in (i)st mwt-ntr $n$ nswt-bity wsr-m3`t-R ${ }^{\top} s t p-n-R^{\top} s 3-$ $R^{\ulcorner}$mry-Imn $R^{\ulcorner}-m s w$ ink mwt.k wrt hkjw ir.n.i st.i hr tp.k $r \underline{d} t$ di ${ }^{\complement} n h \underline{d} \underline{d d}$ $w 3 s \underline{d} t$, "Words spoken by Isis, the god's mother, to the King of Upper and Lower Egypt: wsr-m3`t-R $s t p-n-R^{\complement}$, the son of Rê, $m r y-$ Imn $R^{\top}-m s w$, I am your mother, great of magic, I made my throne upon your head eternally, given life, stability and dominion, eternally" [Fig. 2a $(1,2,3)]$. Goddess Hathor text can be read from left to right as follows: $\underline{d} d \mathrm{mdw}$ in Ht-Hr nbt htpt $n$ nswt-bity wsr-

\footnotetext{
${ }^{6}$ F. Petrie, Koptos (London, 1896), 15, n. 25, pl. XVII; L. Borchardt, Statuen und Statuetten Königen und Privatleuten Catalogue Général des Antiquités Egyptiennes du Caire, 4, col. 2 (Berlin, 1925), 102103, pl. 93; J. Vandier, Manuel d'Archéologie Egyptienne, Tome III. Les Grandes Epoques. La Statuaire (Paris, 1958), pl. CXXIX; J. Vandier, "Iousâas et (Hathor) Nébet Hétépet", $R d E 16$ (Paris, 1964), 81-82; C.D. Noblecourt, La Femme au Temps des Pharaons (Paris, 1985), n. 80; H. Sourouzian, "Standing Royal Colossi of the Middle Kingdom Reused by Ramses II", MDAIK 44 (Kairo-Berlin, 1988), 235, note 27; M. EatonKrauss, "Ramses-Re Who Creates the Gods", in: R. Bleiberg, Fragments of a Shattered Visage. The Proceedings of the International Symposium on Ramesses the Great (Tennessee, 1993), 19, pls. 1-2; C. Vandersleyen, "Ramsès II Admirait Sésostris I", Chief of Seers. Egyptian Studies in Memory of Cyril Aldred (London, 1997), 285-287, figs. 1-4; H. Sourouzian, Features, 109, note 62.
} 


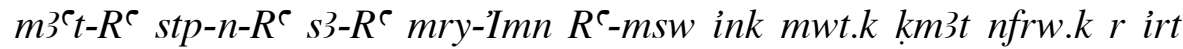
$h h w$ m $m$ ḥbw mi Pth-t3-țnn di 'nh mi $R^{e} \underline{d} t$, "Words spoken by Hathor, the mistress of Hetepet, to the King of Upper and Lower Egypt, wsr$m 3^{\top} t-R^{\top} s t p-n-R^{\complement}$, the son of Rê, mry-Imn $R^{\complement}-m s w$, I am your mother, who creates your beauty, to make thousands of festivals, like PtahTatenen, given life like Rê, eternally" [Fig. 2a (4, 5, 6)].

The inscriptions on the back pillar right side are as follows: (1) $h h \mathrm{hw}$ $m$ hbw hfnw $m$ rnpwt $n$ nswt-bity $n b$ t3wy wsr-m3`t-R` stp $n R^{\ulcorner} s^{3}-R^{\odot}$ $n b h^{\top} w$ mry-Imn $R^{\top}-m s w \underline{d} t$, "Thousands of festivals, millions of years to the King of Upper and Lower Egypt, the lord of the two lands, wsr $m 3^{\top} t-R^{\top} s t p-n-R^{c}$, the son of Rê, the lord of appearance, $R^{\top}-m s w$, eternally" [Fig. $2 \mathrm{~b}(1)]$. The text on the throne right side is as follows:

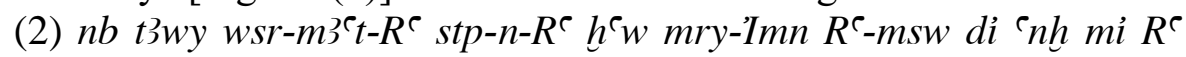
mry (i)st wrt mwt-ntr hnwwt t3wy, "The lord of the two lands, wsr-m3't$R^{\Upsilon} s t p-n-R^{\Upsilon}$, the lord of appearance, $m r y-\operatorname{Imn} R^{\complement}-m s w$, given life like Rê, the beloved of Isis the great, the royal mother, the mistress of the two lands" [Fig. 2b (2)]. The inscriptions on the back pillar left side are as follows: (3) hhhw $m h b w h r$ st $H r \underline{d} t m$ ' $n h \underline{h} \underline{d} d w 3 s n$ nswt-bity wsr-m3't-R ${ }^{\top} s t p-n-R^{\top}$ mry-Imn $R^{\top}-m s w \underline{d} t$, "Thousands of festivals, on the throne of Horus eternally, with life, stability and dominion, to the King of Upper and Lower Egypt, wsr-m $3^{\complement} t-R^{\complement} s t p-n-R^{\complement}$, the son of Rê, $m r y$-Imn $R^{\complement}-m s w$, eternally" [Fig. 2b (3)]. The text on the throne left side is as follows: (4) $n b$ t3wy wsr-m3`t-R $R^{\ulcorner} s t p-n-R^{\top} n b h^{\top} w$ mry-Imn $R^{\top}-m s w$ di ${ }^{\top} n h$ mi $R^{\top}$ mry Ht-Hr nbt htpt nbt pt, "The lord of the two

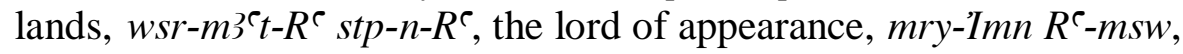
given life like Rê, the beloved of Hathor, the mistress of Hetepet, the mistress of the sky" [Fig. 2b (4)]. ${ }^{7}$

\section{Statue 3: A Seated Dyad of a King and God Ptah-Tatenen (PL. 3)}

This dark-red granite dyad, which measures 1, $68 \mathrm{~m}$ height, ${ }^{8}$ was found in Memphis. ${ }^{9}$ It is now exhibited in the Egyptian Museum in Cairo under number CG 554. ${ }^{10}$ It portrays King Ramses II (originally

\footnotetext{
${ }^{7}$ Vandersleyen, Chief of Seers, 285-287, figs. 1-4.

${ }^{8}$ PM III, 835.

${ }^{9}$ Memphis, now Mit Rahineh-Elbadrasheen-Giza Governorate, is the Greek word for the first capital of unified Egypt, founded by Narmer. It was called in Egyptian inb-HD "The white wall", and mn-nfr "Stable and beautiful"

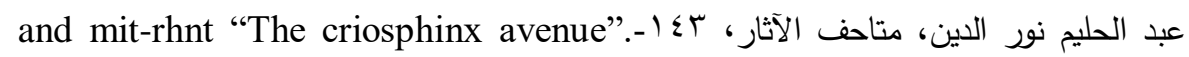
$.1 \leq \varepsilon$

${ }^{10}$ PM III, 835.
} 
King Senousert I, XII Dynasty) and God Ptah-Tatenen.

The king and the god are seated next to each other on a cubic throne with a high backrest. The king is wearing a royal striated nemes with a frontal coiled uraeus, a false beard slightly broken, a large beaded $w s h$ collar, and a royal $̌ n d y t$ kilt and is placing both hands flat on his knees. Between the king's legs, the tail of the bull is drawn in relief. The god is wearing a long tripartite wig, a collar and a pleated kilt. $\mathrm{He}$ is as well holding the king with his right arm, while his left palm is resting flat on his knee, holding the sign of ${ }^{2} n h$. The throne both sides are ornamented with the papyrus and the lotus (symbols of Upper and Lower Egypt) knotted together, composing the sm3 t3wy sign, "The union of the Two Lands".

The name and titles of King Ramses II are carved on the dyad. The vertical text inscribed to the right of the king's right leg is topped by the sign of the sky ${ } p t$ and it can be read from right to left as

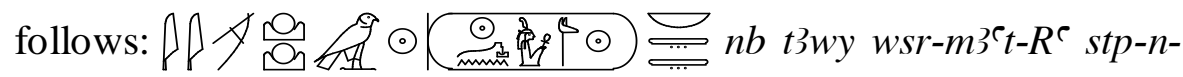

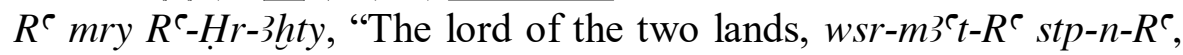
the beloved of Rahorakhty". The vertical text to the left of the god's left leg can be read from left to right as follows:

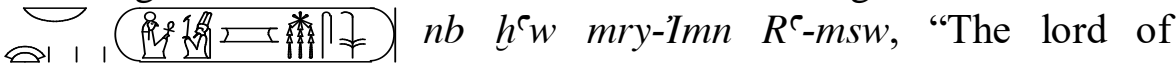
appearance, mry-Imn $R^{c}-m s w "$ ". The two cartouches inscribed between the legs of the two statues are topped by the sky sign $\varpi p t$

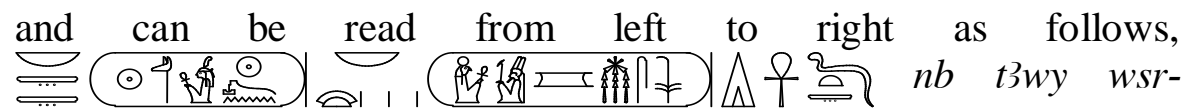
$m 3^{\top} t-R^{\top} s t p-n-R^{\top} n b h^{\top} w$ mry-Imn $R^{\top}-m s w$ di ${ }^{\top} n h \underline{d} d t$, "The lord of the two lands, wsr-m3 ${ }^{\top} t-R^{\top} s t p-n-R^{\top}$, the lord of appearance, mry-Imn $R^{\top}$ $m s w$, given life eternally".

Four vertical columns are engraved on the backrest. To the right hand side, the first and the second columns are facing right, whereas the third and the fourth ones to the left hand side are facing the left: $\mathrm{Hr}$ $k 3$ nht mry m3`t nb t3wy wsr-m3`t-R` stp-n-R` nb h'w mry-Imn $R^{\top}-m s w$ (.....) it.f Pth-t3-tnnn di ${ }^{\top} n h \underline{d} \underline{d}$, "Horus, the strong bull, the beloved of Maât, the lord of the two lands, wsr-m3et-Re $s t p-n-R^{c}$, the lord of appearance, mry -Imn $R^{c}-m s w$, given life eternally" [Fig. $\left.3(1,2)\right] . H r$

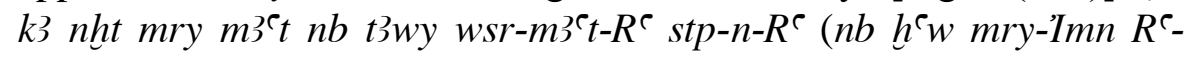
$m s w$ (....) di ${ }^{\top} n h$ mi $R{ }^{c}$, "Horus, the strong bull, the beloved of Maât,

${ }^{11}$ Borchardt, Statuen II, 101-102, pl. 93; Vandier, Manuel, pl. CXXVIII; Sourouzian, Features, 235, note 27. 
the lord of the two lands, wsr-m3et-Re stp-n-Re, the lord of appearance, mry-Imn $R^{\top}$-msw, (....), given life like Rê” [Fig. 3 (3, $4)] .^{12}$

\section{Single SEATEd Statues}

\section{Statue 4: A Seated Royal Colossus (Pl. 4)}

This grey granite statue, which measures $3.20 \mathrm{~m}_{\text {height }}{ }^{13}$ was found in Tanis. ${ }^{14}$ It is now exhibited in Berlin Museum under number 7264. ${ }^{15}$ It is inscribed with the names of Kings Ramses II and Merenptah (originally of King Senousert II, XII Dynasty). The king is sitting on a cubic low backrest throne, wearing the royal striated nemes with frontal coiled uraeus, a striped false beard, a large wsh collar and a royal šndyt kilt held by a belt. Under the $w s h$ collar, there is a sculpted square pectoral on the chest with a vertical cartouche carved under it. The cartouche is surmounted by a sun disk, flanked by two uraei, topped by the white crown. The king's right hand is clenched vertically on his thigh and his left open hand is positioned flat on his thigh. His bare feet are resting on a rectangular pedestal. The statue bears the names of Kings Ramses II and Merenptah. ${ }^{16}$

The vertical cartouche under the pectoral is inscribed with the name of King Merenptah: buckle and the pendant of the kilt's belt are engraved with King

\footnotetext{
${ }^{12}$ Borchardt, Statuen II, 101-102, pl. 93.

${ }^{13}$ PM IV, 22.

${ }^{14}$ Tanis, in Egyptian $\underline{d}^{\top} n t$, in Arabic San-Elhaggar, is one of the villages of Elhusseineya- El Sharqeya Governorate. It was the capital of Egypt during Dynasty XXI, and the capital of the Nineteenth Nome of Lower Egypt.
}

${ }^{15}$ PM IV, 22.

$$
\text { ؛ عبد الحليم نور الدين، متاحف الآثار، 0؟. }
$$

${ }^{16}$ H. Evers, Staat aus dem Stein, I (München, 1929), pl. 64; H. Evers, Staat aus dem Stein, II (Müchen, 1929), 676-687; K. Kitchen, Ramesside Inscriptions, IV (Oxford, 1982), 44 (4); P. Lacovara and N. Reeves, "The Colossal Statue of Mycerinus Reconsidered", RdE 38 (Paris, 1987), note 11; H. Sourouzian, "Les Monuments du Roi Merenptah", SDAIK 22 (Mainz, 1989), 94-95, doc. 47; B. Fay, The Louvre Sphinx and Royal Sculpture from the Reign of Amenemhat II (Mainz, 1996), 59, pls. 75-77; H. Sourouzian, "A Headless Sphinx of Sesostris II from Heliopolis in the Egyptian Museum, Cairo. JE 37796", Studies in Honor of William Kelly Simpson (Boston, 1996), 752, note 37; K. Kitchen, Ramesside Inscriptions, II (Oxford, 1999), 299, n. 18. 


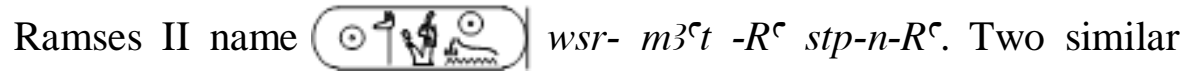
vertical texts of King Ramses II are flanking the colossus legs: $n s w t$ -

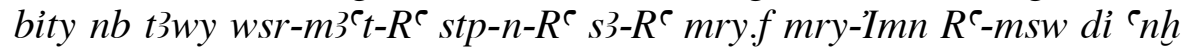
mi $R$, "King of Upper and Lower Egypt, lord of the two lands, wsr$m{ }^{`} t-R^{\complement} s t p-n-R^{\complement}$, son of Rê, his beloved, mry-Imn $R^{\top}-m s w$, given life like Rê" (Fig. 4).

On the base, to the right of the king's right foot, the vertical text from right to left can be read as follows: $t 3 w y$ wsr- $m 3^{\top} t-R^{\complement} s t p-n-R^{\complement}$, "The good god, lord of the two lands, wsr$m 3^{\prime} t-R^{r} s t p-n-R^{C}$. On the other side of the base, to the left of the king's left foot, the vertical text from left to right can be read as

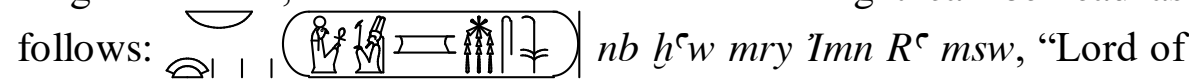
appearance, mry 'Imn $R^{\complement}$ msw".

The base frontal side is inscribed by a symmetrical horizontal text, divided in the middle with the sign of $f^{\circ} n h$, the text bears the name of King Merenptah: (kin nswt-bity b3-n-R` mry Imn, "May he live, King of Upper and Lower Egypt, $b 3-n-R^{\top}$ mry-Imn". On the right side of the base, a remaining horizontal text of King Merenptah can be read as follows: ․ㅡ (...) mry (St) 3 phty nswt-bity b3-n-R` mry-Imn s3-R $R^{\top}$ mry-(n)-Pth (htp-hr-m3't), "(Beloved of Seth), great of power, King of Upper and Lower Egypt, b3-n-Re mry-Imn, son of Rê, mry-(n)-Pth, (htp-hr$m 3 t) "$

On the left side of the base, another horizontal text of Merenptah reads as follows:

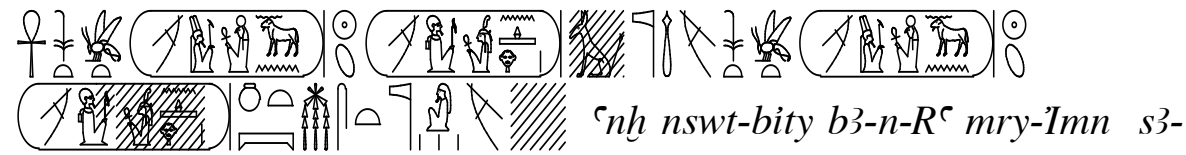
$R^{\top}$ mry-n-Pth htp-hr-M3`t mry (St) ntrr ${ }^{\top} 3$ nswt-bity b3-n-R` mry-Imn s3-R $R^{\top}$ mry (n) Pth (htp-hr)- m3`t mry Nwt mst ntrw (...), "May he live, the King of Upper and Lower Egypt, $b 3-n-R^{\top} m r y-I m n$, son of Rê, Merenptah, beloved of (Seth), the great god, King of Upper and Lower Egypt, $b 3-n-R^{\top} m r y-I m n$, son of Rê, $m r y$-(n)-Pth (htp-hrr) $m 3^{\top} t$, beloved of Nut, who engendered the gods, (...)". ${ }^{17}$

${ }^{17}$ Sourouzian, Merenptah, 94-95, doc. 47. 


\section{Statue 5: A Seated Royal Colossus (Pl. 5)}

This black granite statue, which measures $2.10 \mathrm{~m}$ height, was found in Tanis. It is now exhibited in the Egyptian Museum in Cairo under number CG 430. ${ }^{18}$ It represents King Ramses II (originally King Senousert II, XII Dynasty) seated on a cubic throne propped by a narrow high backrest. The king is wearing a striated nemes with a frontal coiled uraeus. The nemes, knotted at the back, reaches the backrest. Two falcons, topped by the double crown, flank the knot. $\mathrm{He}$ is also dressed in a royal šndyt kilt. His clenched right hand is resting vertically holding a folded cloth, while his left hand is put flat on his knee. His bare feet are resting on a rounded pedestal. The throne both sides are ornamented with the Lotus and Papyrus knotted together (symbols of Upper and Lower Egypt) in sunken relief, composing the sign of the $s m 3 t 3 w y$, "The union of the Two Lands".

The colossus is carved with King Ramses II name. Beside the legs of the king, two identical texts are inscribed vertically: nswt bity $n b$ t3wy wsr-m3`t-R` $s t p-n-R^{\top} s 3-R^{\top}$ mry-Imn $R^{\top}-m s w \underline{d} t$, "The King of Upper and Lower Egypt, the lord of the two lands, wsr-m3't-R ${ }^{c} s t p-n-R^{c}$, the son of Rê, mry-Imn $R^{\top} \mathrm{msw}$, eternally" (Fig. 5a). On the throne's right side, the text is inscribed in four vertical columns: The first column from the right reads: $m r y-R^{-}-H r-3 h t y$, "The beloved of Rahorakhty". The second one reads: mry-Imn $R^{\top}-m s w$. The third one reads: $w s r-m 3^{\complement} t-R^{\top} s t p-n-R^{\top}$.

The last one reads: mry Tm $n b$ Iwnw, "The beloved of Atum, lord of Heliopolis" (Fig. 5b). On the throne's left side, the inscriptions above the $s m 3$ t $3 w y$ are engraved in four vertical columns. From the right, the first column can be read as follows: mry Imn-R $R^{c} n b$ pt, "The beloved of Amun-Rê, lord of the sky". The second one reads: mryImn $R^{\top}-m s w$. The third reads: wsr-m ${ }^{\top} t-R^{\top}$ stp- $n-R^{\top}$. The last reads: mry Pth nb m3`t, "The beloved of Ptah, lord of justice" (Fig. 5c). The back pillar is inscribed with four vertical columns: The second and the first columns from the right can be read as follows: $\mathrm{Hr} k 3-n h t$ mry

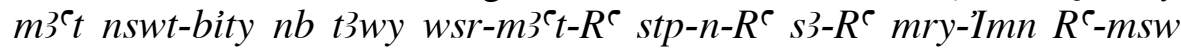

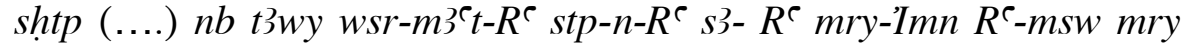
$N w t$, "Horus, the strong bull, the beloved of Maât, the King of Upper and Lower Egypt, the lord of the two lands, wsr-m3`t-R ${ }^{\top} s t p-n-R^{\top}$, the son of Rê, $m r y-I m n R^{\top}-m s w,(\ldots)$, the lord of the two lands, wsr-m3't$R^{\ulcorner} s t p-n-R^{\ulcorner}$, the son of Rê, mry-Imn $R^{\ulcorner}-m s w$, the beloved of Nut" (Fig. 5d). The second and the first columns from left are identically

${ }^{18}$ PM IV, 22. 
inscribed, except for the names of the gods: The god in the second column is Atum and in the first column is Seth". 19

\section{Statue 6: A Seated Royal Colossus (Pl. 6)}

This black granite statue, which measures $2.65 \mathrm{~m}$ height, was found in Tanis. It is now exhibited in the Egyptian Museum in Cairo under number CG 432. It represents King Ramses II (originally King Senousert II, XII Dynasty). This statue is similar to statue 5 (Pl. 5), except that a rectangular pectoral, engraved with three gods figures 造, is sculpted on the king's chest and his feet are rested on a rectangular pedestal. ${ }^{20}$ The colossus is inscribed by King Ramses II name and titles. The belt is carved by a horizontal cartouche as

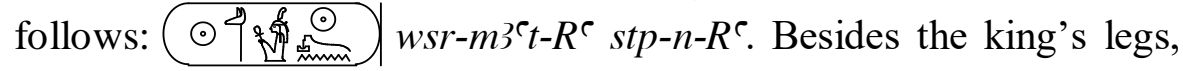
the inscriptions are similar to the inscriptions of statue 5 (Pl. 5).

On the throne both sides, above the sm3 t3wy scene, an identical text

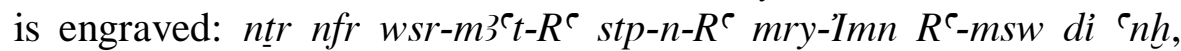
"The good god, wsr-m3't-R ${ }^{\top} s t p-n-R^{\top}$, mry-Imn $R^{\top}-m s w$, given life" (Fig. 6a). The text all around the base begins on the frontal part from the $f$ enh sign and continues to the right and to the left sides. From the sign of $f$ ' $n h$ to the right side: f

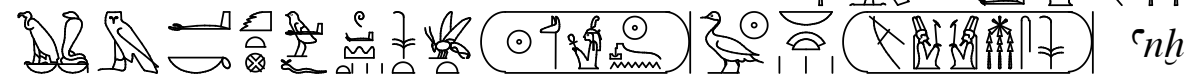

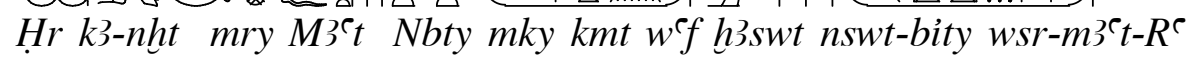
$s t p-n-R^{\top} s 3-R^{\top} n b h^{\top} w$ mry-Imn $R^{\top}-m s w$, "May he live, Horus, beloved of Maat, he who belongs to the two goddesses Nekhbet and Wadjet, the protector of Egypt, who smites the foreign countries, King of Upper and Lower Egypt wsr-m3`t-R $R^{\top} s t p-n-R^{\top}$, son of Rê, lord of appearance, $m r y-I m n R^{`}-m s w$ ". From the sign of $f^{\text { ‘ }} n h$ to the left side, the text is as follows:

\footnotetext{
${ }^{19}$ W.F. Petrie, Tanis, II. Nebesheh and Defeneh (London, 1888), pl. XI (173); Borchardt, Statuen II, 34-36, pl. 70; Evers, Staat I, pls. 67-68; P. Montet, Les Nouvelles Fouilles de Tanis (1929-1932) (Paris, 1932), 10; C. Vandersleyen, Chief of Seers, 285, note 2 on p. 287; H. Sourouzian, "Seth Fils de Nout et Seth d'Avaris dans la Statuaire Royale Ramesside", in: Timelines: Studies in Honour of Manfred Bieteak (Leuven, 2006), 347.

${ }^{20}$ G. Maspero and M.E. Brugsch, La Trouvaille de Deir el-Bahari (Le Caire, 1881), pl. 3 (middle); Borchardt, Statuen II, 37-39, pl. 71; Evers, Staat I, pls. 65-66; Montet, Tanis, 10; Vandier, Manuel, pl. LXI; Vandersleyen, Chief of Seers, 285, note 2 on p. 287; Sourouzian, Avaris, 347.
} 


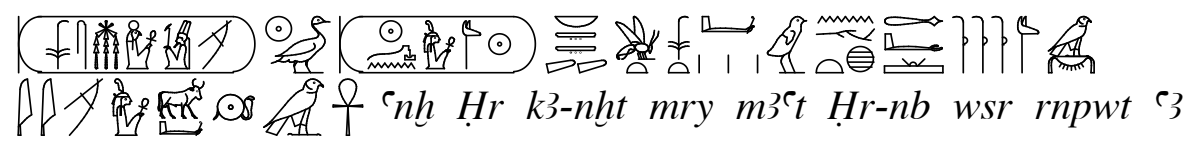

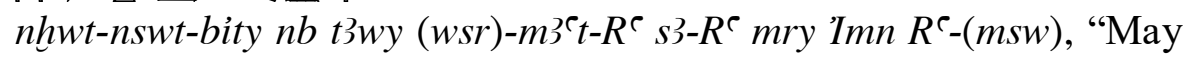
he live, Horus, the strong bull, beloved of Maât, Horus the victorious over Seth, rich of years, great of victories, King of Upper and Lower Egypt, lord of the two lands, (wsr)- $m 3^{\top} t-R^{\top}\left(s t p-n-R^{\top}\right)$, son of Rê, mry-Imn $R^{\mathrm{e}}$-(msw)".

The inscriptions on the backrest are carved in three vertical columns, it can be read as follows: $(1,2) n s w t$-bity wsr-m3 ${ }^{\top} t-R^{\top} s t p-n-R^{\top} s 3-R^{c}$ mry Hpri $n b h^{\top} w$ mry-Imn $R^{\top}-m s w$ mry Imn-R ${ }^{\top}$, nswt-bity nb t3wy mry

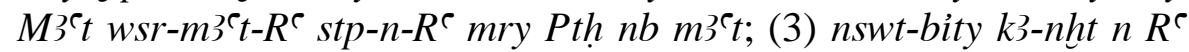
wsr-m3`t-R` stp-n-R` (mry) $R^{\top}-H r-3 h t y ;(1,2)$ "The King of Upper and Lower Egypt, wsr-m3`t-R $s t p-n-R^{\top}$, the son of Rê, the beloved of Khepery, mry-Imn $R^{\top}-m s w$, the beloved of Amun-Rê, the King of

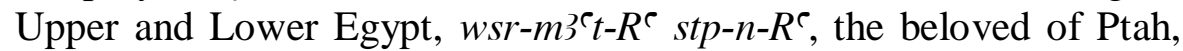
the lord of justice; (3) "The King of Upper and Lower Egypt, the strong bull of Rê, wsr-m3`t-R ${ }^{\ulcorner} s t p-n-R{ }^{\ulcorner}$, (beloved) of Rahorakhty" (Fig. 6b). ${ }^{21}$

\section{Statue7: The Lower Part of a Seated Royal Colossus (PL. 7)}

This black granite statue was found in Bubastis. ${ }^{22}$ The colossus head is now exhibited in Sydney Museum, Australia; its upper part is lost while the damaged lower part is still in situ. ${ }^{23}$ It represents King Ramses II (originally King Senousert II, XII Dynasty) sitting on a cubic throne and wearing the white crown of Upper Egypt. A smaller female figure was probably standing on the throne and holding the nemes of the king with her hands. The throne's left side is ornamented in sunken relief with the heraldic plants of Upper and Lower Egypt, knotted together held by the two Nile Gods Hapy,

\footnotetext{
${ }^{21}$ Maspero and Brugsch, Deir el-Bahari, pl. 3 (middle); Borchardt, Statuen II, 37-39, pl. 71; Evers, Staat I, pls. 65-66; Montet, Tanis, 10; Vandier, Manuel, pl. LXI; Vandersleyen, Chief of Seers, 285, note 2 on p. 287; Sourouzian, Avaris, 347.

${ }^{22}$ Tell Basta or Bubastis is one of the most important archaeological sites at Sharqeya Governorate. It was the capital of the Eighteenth Nome of Lower Egypt and the capital of Egypt during the 12th Dynasty. The Egyptian name was pr-BAstt, "The house of the Goddess Bastet".
}

${ }^{23}$ PM IV, 30.

$$
\text { ؟ ع عبد الحليم نور الدين، متاحف الآثار، }
$$


composing the $s m 3$ t3wy sign, "The union of the Two Lands". ${ }^{24}$ The inscriptions engraved on the sides of the legs of the king are damaged. The throne's left side is carved with King Ramses II name and titles.

Between the two Nile Gods $h^{\complement} p y$; the text is as follows: ntr nfr wsr-

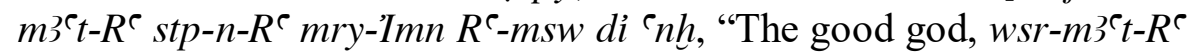
stp-n-Re mry-Imn $R^{e}-m s w$, given life" (Fig. 7). The vertical text on the right, behind the figure of God Hapy, can be read from left to

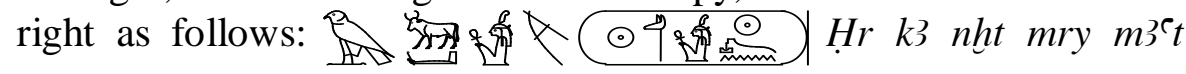
$w s r-m 3^{\top} t-R^{\top} s t p-n-R^{c}$, "Horus, the strong bull, beloved of Maât, wsr$m{ }^{\prime} t-R^{c} s t p-n-R$ ". The horizontal text on the pedestal from left to

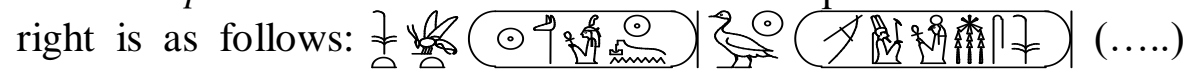

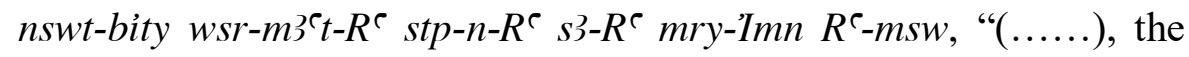
King of Upper and Lower Egypt, wsr-m`t-R`stp-n-R`, the son of Rê, $m r y$-Imn $R^{\complement}-m s w$ ". King Ramses II titles are inscribed as well on the back of the throne, it is depicted in three vertical columns indicating consecutively: "The beloved of Rê-Horakhty, Amun-Rê and the one of Ombos". 25

\section{Statue 8: The Lower Part of a Female Seated Royal STATUE (PL. 8)}

This black granite statue was found in Tanis. It is now exhibited in the Egyptian Museum in Cairo under number 99. The colossus is entirely damaged except its lower part from the waist to the middle part of the legs. It goes back to the reign of King Ramses II (originally to the reign of King Senousert II, XII Dynasty). ${ }^{26}$ The statue represents a princess seated on a cubic throne, placing her palms flat on her thighs and dressed in a pleated ankle-length tight garment. The left side of the throne is carved with the name of Tuy, King Ramses II mother. ${ }^{27}$

Statue 9: A Seated Royal Colossus (Pl. 9)

This unpolished light-yellow quartzite colossus, which measures 2.26

24 E. Naville, Bubastis (London, 1891), 9, 14, 37, pls. XXV(c), XXXVIII (a); Sourouzian, Avaris, 347, n. 12.

25 Sourouzian, Avaris, 347.

26 PM IV, 19.

27 A. Mariette, in: Recueil de Travaux Relatifs à la Philologie et l'Archéologie Egyptiennes et Assyriennes (Le Caire, 1887), pls. IX, X 14 [VIII]; W.F. Petrie, Tanis, I (London, 1885), 6-7, pl. XIV (1). 
$\mathrm{m}$ height and $0.73 \mathrm{~m}$ width at the bottom, was found in Ehnasya. ${ }^{28} \mathrm{It}$ is now exhibited in University Museum, Philadelphia under number E 635. It represents King Ramses II (originally King Senousert III, XII Dynasty). The king is portrayed sitting on a cubic throne propped by a narrow low backrest, wearing a striated nemes with a frontal coiled uareus and a pleated royal šndyt kilt.

The lower part of his arms is lost while his both open palms are resting flat on his thighs. Between the king's legs, the tail of the bull is drawn in relief. His bare feet are placed on a high rectangular pedestal. The colossus is carved with King Ramses II name. The king's legs are flanked by two identical texts, facing one another: $n b t 3 w y$ wsr-m3 $t-R^{c}$ $s t p-n-R^{\ulcorner} n b h^{\ulcorner} w$ mry 'Imn $R^{\top}-m s w$, "The lord of the two lands, wsr-m3`t$R^{\ulcorner} s t p-n-R^{\ulcorner}$, lord of appearance, mry 'Imn $R^{\ulcorner}-m s w$ " (Fig 8a). The frontal part of the base is inscribed by two vertical cartouches of King Ramses

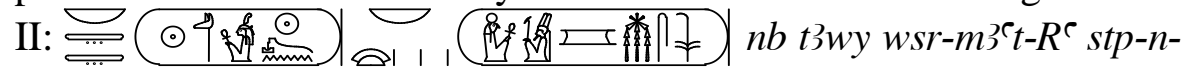
$R^{\ulcorner} n b h^{\ulcorner} w$ mry-Imn $R^{\top}-m s w$, "The lord of the two lands, wsr-m3`t-R $R^{\ulcorner}$ $s t p-n-R^{\complement}$, lord of appearance, $R^{\top}-m s w^{\prime \prime}$.

Two symmetrical texts are flanking these cartouches on both sides, and extending to the two sides of the base:

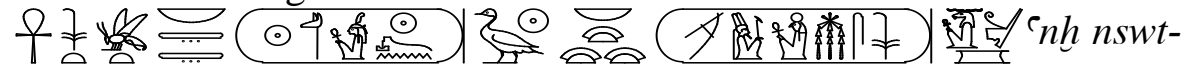

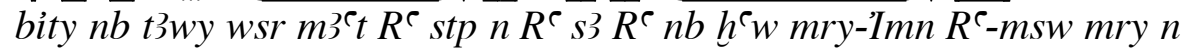
$H r-\breve{s}$.f, "May he live, King of Upper and Lower Egypt, lord of the

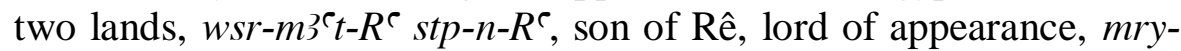
Imn $R^{\top}-m s w$, beloved of Harshaphes". The text inscribed to the left side of the throne reads:

1. From left to right: $\mathrm{Hr} k 3$ nht $s 3$ Pth, "Horus, the strong bull, the son of Ptah".

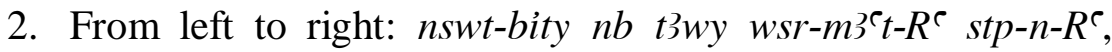
"King of Upper and Lower Egypt, wsr-m3"t-R $s t p-n-R^{\top}$ ".

3. Is supposed to be read from right to left: $s 3-R^{\top} n b h^{\top} w$ mry Imn $R^{\complement} m s w$, "The son of Rê, lord of appearance, mry-Imn $R^{\ulcorner}$$m s w "$.

\footnotetext{
${ }^{28}$ Ehnasya is one of the towns of Beni-Sueif Governorate; it was the capital of the twenty-first capital of Upper Egypt. It is called as well Ehnas and Ehnas-Elmedineh, deriving from the Egyptian word "The residence of the royal child". The Greeks called it Herakleopolis "The city of Hercules". It was the capital of Egypt during the 9th and 10th Dynasty, during the conflict between Ehnasya and Thebes.
}

$$
\text { ؛ عبد الحليم نور الدين، متاحف الآثار، 14 ا-97 ا. }
$$


4. From right to left: $\mathrm{Hr} k 3$ nht mry $\mathrm{m}^{3}{ }^{\mathrm{C}} \mathrm{t}$, "Horus the strong bull, beloved of Maât" (Fig 8b). ${ }^{29}$

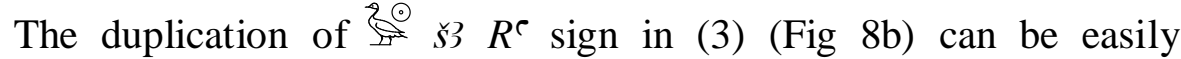
observed as both signs are in opposite directions. Miller said that when the statue arrived at the museum, this duplication was covered partly with plaster, then later it fell down and the duplication was exposed. ${ }^{30}$ Ostensibly, it was the sculptor's mistake. Finally, the names and titles of King Ramses II are inscribed on the throne's rear back. ${ }^{31}$

\section{Statue 10: A Seated Royal Colossus (Pl. 10)}

This yellow quartzite colossus was found in Ehnasya, in Kom ElAkareb, south of Harshaphes temple, in the destroyed temple of King Ramses II. It measures $4.35 \mathrm{~m}$ height, $2.34 \mathrm{~m}$ width and is now exhibited in the Egyptian Museum garden in Cairo under number JE 45975 next to statue $11 .^{32}$ This statue is similar to statue 11 found together at the same place and represents King Ramses II (originally King Senousert III, XII Dynasty). The king is sitting on a cubic throne with a small narrow backrest, wearing the nemes with a frontal coiled uraeus, a large wsh collar and a pleated royal šndyt kilt held by a belt ornamented with zigzag lines. The tail of the bull is visible in relief between the king's legs. His two palms are rested flat on his thighs while his bare feet are placed on a high rectangular pedestal. The king's legs are flanked by two small figures of princesses. They are wearing long tight pleated garments. The one to the king's right leg is Meritamon and the other one to the king's left leg is Bentanat. The statue is engraved with King Ramses II name. ${ }^{33)}$

The remaining text on the kilt's belt is as follows, from right to left:

${ }^{29}$ E. Naville, Ahnas el Medineh (London, 1894), 11, pl. X; W.F. Petrie, Ehnasya (London, 1905), 15, 55 ff; Ph. Miller, "A Statue of Ramses II in the University Museum, Philadelphia”, JEA 25, I (London, 1939), 1-7, pls. I-III; G. Fischer, "The Mark of a Second Hand on Ancient Egyptian Antiquities", MMJ 9 (New York, 1974), 6, fig. 2 on p. 7.

${ }^{30}$ Miller, JEA 25, 2.

${ }^{31}$ Naville, Ahnas el Medineh, 11, pl. X; Petrie, Ehnasya, 15, 55 ff; Miller, JEA 25, 1-7, pls. I-III; Fischer, MMJ 9, 6, fig. 2 on p. 7.

${ }^{32}$ PM IV, 121.

${ }^{33}$ G. Daressy, "Deux Statues de Ramsès II d'Hérakleopolis", ASAE 17 (Le Caire, 1917), 33-38; Evers, Staat II, pls. XI (71), XVI (69, 70); M.G. Mokhtar, "Ihnasya el Medina (Herakleopolis Magna)", BdE 40 (Cairo, 1983, 89-90, pl. VII (B); Sourouzian, Merenptah, 109-110, doc. 63. 
ntr $n f r(\ldots .) n b t 3 w y.(\ldots) k 3,.(\ldots .$.$) , "The good god, the lord of the$ two lands, (....) k3" (Fig. 9a). Above the left princess's head, a vertical text can be read from left to right as follows:

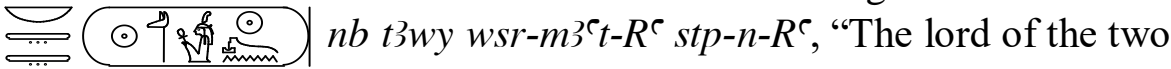

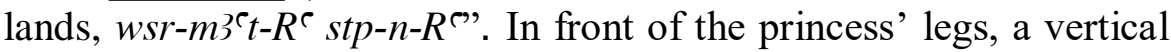
inscription on the base is as follows:

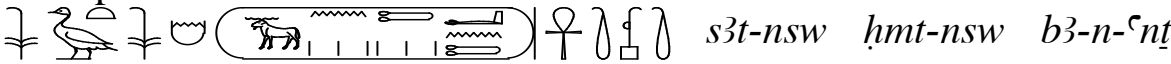
'nh.ti rnp.ti, "The royal daughter, the royal wife, $b 3-n$ - $n t$, may she live and be prosperous". Above the right princess's head, a vertical

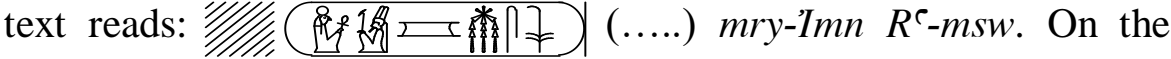

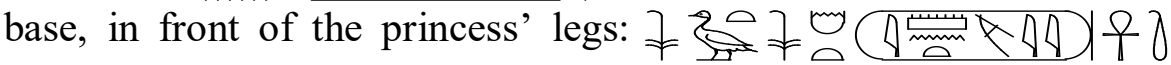
s3t-nsw hmt-nsw mryt-Imn 'nh.til, "The royal daughter, the royal wife, mryt-Imn, may she live".

The throne's both sides are inscribed by four vertical columns and one horizontal line below the cartouches. The first and the last columns are as follows: $(1,4) \mathrm{Hr} k 3-n h t$ mry $\mathrm{M}^{3} \mathrm{t}$ "Horus, the strong bull, beloved of the Goddess Maât". The second one from the left reads: (2) $s 3-R^{\complement} n b h^{\complement} w$ mry-Imn $R^{\top}-m s w$, "The son of Rê, lord of appearance, $m r y-I m n R^{c}-m s w$ ". The second one from the right can be read: (3) nswt-bity nb t3wy wsr-m3`t-R $R^{\top} s t p-n-R^{e}$ "King of Upper and Lower Egypt, lord of the two lands, wsr-m3't-R $R^{\top} s t p-n-R^{\curvearrowright}$ ". The horizontal text is as follows: di 'nh mi $R$ ', "Given life like Rê" (Fig. 9b).

Two vertical texts, facing each other, are inscribed on the small back pillar: Wsir, "The son of Rê, mry-Imn $R^{\top}-m s w$, beloved of Osiris".

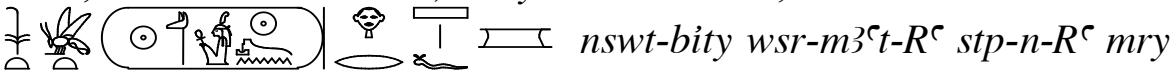
$H r-\breve{s}$.f, "King of Upper and Lower Egypt, wsr-m3't-Re stp-n-Re, beloved of Harshaphes". On the throne's rear back, below the back pillar, the inscriptions are similar to those on the two sides of the throne (Fig. 9b). The inscriptions on the pedestal sides and on the front of the base are destroyed. ${ }^{34}$

\section{Statue 11: A Seated Royal Colossus (Pl. 11)}

This yellow quartzite colossus was found in Ehnasya at Kom ElAkareb, south of the temple of Harshaphes, in the destroyed temple of

${ }^{34}$ Daressy, ASAE 17, 33-38; Evers, Staat II, pls. XI (71), XVI $(69,70)$; Mokhtar, BdE 40, 89-90, pl. VII (B); Sourouzian, Merenptah, 109-110, doc. 63. 
King Ramses II. It measures $3.90 \mathrm{~m}$ height, $1.03 \mathrm{~m}$ width and is now exhibited in the Egyptian Museum garden in Cairo under number JE 45976, next to statue $10(\mathrm{Pl} .10){ }^{35}$ This statue is similar to statue 10 found together at the same place and represents King Ramses II then King Merenptah (originally King Senousert III, XII Dynasty). This colossus is identical to statue 10, except for the measurements and the inscriptions. This colossus is identically inscribed as statue 10: On the throne two sides, the dorsal pillar and below the back pillar on the throne's rear back. The texts of the two princesses do not include their names, but bear only King Ramses II name and titles as statue 10.

Also, the belt of the kilt is carved with King Ramses II titles. Moreover, the cartouches of King Merenptah have been added on the chest, on the right and left shoulders: $b 3-n-R^{\top}$ mry-Imn mry-n-Pth htp$h r-m 3^{C} t$ (Fig. 10a). The inscriptions on the front of the pedestal consist of four vertical columns, the first and last columns read: mry $H r$ - ̌. $f$ nb Nni-nsw, "The beloved of Harshaphes, the lord of Ehnasya". The second and third columns from the left are the cartouches of King Ramses II: $n b$ t3wy wsr-m3 ${ }^{\top} t-R^{\top} s t p-n-R^{\top} n b h^{\top} w$ $m r y$-Imn $R^{\top}-m s w$ di ${ }^{\top} n h$ mi $R^{\top}$, "The lord of the two lands, wsr-m3't$R^{\top} s t p-n-R{ }^{\Upsilon}$, lord of appearance, mry-Imn $R^{\top}-m s w$, given life like Rê" (Fig. 10b). The inscriptions on the sides of the pedestal are as follows: f₹

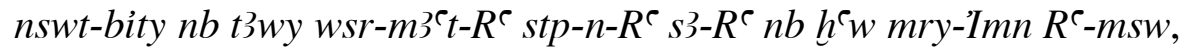
"Long live the King of Upper and Lower Egypt, lord of the two lands, wsr-m3`t-R $s t p-n-R^{\top}$, son of Rê, lord of appearance, mry-Imn $R^{\top}-m s w "{ }^{36}$

\section{ANALYSIS}

Of the Egyptian art, the Middle Kingdom's royal sculptures have a glorified role because of the accurate portrayal of the facial features and attributes of each king in a specific phase of his life. In this era, Egyptian kings and queens are portrayed with an amazing realism, which is a singular phenomenon of the ancient Egyptian art. ${ }^{37}$

Those Middle Kingdom Royal statues, especially the Twelfth

\footnotetext{
${ }^{35} P M$ IV, 121.

${ }^{36}$ Daressy, ASAE 17, 33-38; Evers, Staat II, pl. XVI (70); Mokhtar, BdE 40, 89-90, pl. VII (A); Sourouzian, Merenptah, 109-110, doc. 63.

${ }^{37}$ W. Hayes, "Royal Portraits of the Twelfth Dynasty", BMMA 5 (New York, 1946-1947), 119; C. Aldred, "Some Royal Portraits of the Middle Kingdom in Ancient Egypt", MMJ 3 (New York, 1970), 27.
} 
Dynasty, bring a rich artistic heritage. Some statues could not be identified due to their re-inscription and re-usage by the Nineteenth Dynasty kings. ${ }^{38}$ Unfortunately, the number of the Eleventh Dynasty statues is less than those of the Twelfth Dynasty. ${ }^{(39)}$ There are three schools of royal sculpture during the Twelfth Dynasty:

- The Idealistic School (King Amenemhat I and King Senousert I): Memphis was the center of this school. Its goal was to present an ideal portrait of the king characterized by immortal youth and an expressionless statue face.

- The Classical SCHOOL (King Amenemhat II and King Senousert II): This school is between the idealistic and realistic schools. It embraces the same idealistic art but the difference is obvious in personal characteristics and features as the statues of both kings but with no wrinkles.

- The Realistic SCHOOL (King Senousert III and King Amenemhat III): Thebes was inception place of this school. It represents deep expressional realism. For example, a king is portrayed for the first time with wrinkles and large ears. ${ }^{40}$

New Middle Kingdom art features were not clearly evident until the reign of King Amenemhat I and his son King Senousert I. Many of their statuary from several sites in Upper and Lower Egypt still exist. Those statues cover a range of subjects, from sphinxes and standing or seated colossi to statuary of a more life-sized. Also, it was illustrated that the impressive colossal size and brutal appearance of their huge granite statues found in Delta emphasize the perception of the king as a ruthless ruler. ${ }^{41}$ The main prominent feature of all royal sculptures of the Twelfth Dynasty is the strong bony structure of the face especially the heavy eyebrows, heavy-lidded eyes, huge ears (a marked family characteristic), high cheekbones, a full bulging sullen

\footnotetext{
${ }^{38}$ Sourouzian, Features, 103.

${ }^{39}$ C. Aldred, Egyptian Art in the Days of the Pharaohs (London, 1985), 115; M. Saleh and S. Sourouzian, The Egyptian Museum Cairo. Official Catalogue (Mainz, 1987), n. 67; Sourouzian, MDAIK 44, 252; A. ElShahawy, The Ancient Egyptian Museum in Cairo. A Walk through the Alleys of Ancient Egypt (Cairo, 2005), 107, n. 65.

${ }^{40}$ Vandier, Manuel, 261-268;

$$
\text { ؛ شويكار محمد سلامة، دراسات في تاريخ الفن المصري القديم منذ أقدم العصور وحتى نهاية }
$$

${ }^{41}$ Aldred, Portraits, 38; Aldred, Egyptian Art, 124.
} 
mouth, and a pensive gazing expression and sometimes melancholy. ${ }^{42}$ The following analysis tries to credit each seated statue reused by King Ramses II (XIX Dynasty) to its original king from the Middle Kingdom.

\section{StATUES ASCRIBED TO King AMENEMHAT I}

Although there are not numerous statues of King Amenemhat I for a thirty years reign, they show different types of statues with wellpreserved iconography, and consequently, they provide a good range of reliable dating criteria. ${ }^{(43)}$ The seated colossal statue of King Amenemhat I (Pl. 12), displayed in the Egyptian Museum under number JE 37470), ${ }^{(4)}$ is an important juncture between the statues of the Eleventh and Twelfth Dynasties. This statue is an outcome of the north and the south union. Additionally, the royal statuary became propped by a back pillar, and the throne's two sides were ornamented with royal cartouches and the two heraldic plants (symbols of Upper and Lower Egypt) knotted together held by the two Nile Gods Hapy, composing the sign of the sm3 $t 3 w y$, "The union of the Two Lands". This artistic feature became henceforth an integral part of the royal statuary of the Middle Kingdom. ${ }^{(45)}$

Additionally, new peculiar characteristics in the iconography and style of the royal statue were observed: The oval face with full cheeks with a benevolence expression instead of being motionless; the small structured ears with fleshy ear-laps; the reduced distance between the eyes by sculpting the eyebrows close to each other; the extended cosmetic lines going parallel to the rounding of the bones; the smaller eyes with a larger ground to mitigate the motionlessness of the Eleventh Dynasty; the inner canthi extended downwards on the sides of the nose which became shorter with an enlarged base, a narrow foot and flanked by two modeled muscles; the protruding mouth to match the oval face and the large rounded well modeled chin. ${ }^{(46)}$

Regarding the king's composition, his shoulders, arms and chest are

\footnotetext{
${ }^{42}$ Hayes, BMMA 5, 119.

${ }^{43}$ C. Vandersleyen, L'Egypte et la Vallée du Nil, 2 (Paris, 1995), 43-55; Sourouzian, Features, 103-104.

${ }^{44}$ W.F. Petrie, Tanis I, plan no. 103, pls. 1, 3, XIII; W.F. Petrie, Tanis II, 15-16; W.F. Petrie, A History of Egypt, I (London, 1923), 155, fig. 94.

${ }^{45}$ Evers, Staat I, 22-26, pls. 15-16; Sourouzian, Features, 104.

${ }^{46}$ H. Gauthier, "Une Nouvelle Statue d'Amenemhat 1 er". Mélanges Maspero I, MIFAO LXVI, (Le Caire, 1935), 46, pls. I-II; Evers, Staat I, 2226; Sourouzian, Features, 104.
} 
smoothly formed. The chest is short and the waist is high. Therefore, the belt is placed high on the torso, which in turn makes the kilt visible to a great extent on the back of the statue. The king often puts his hands flat on his knees. The right hand grasps a kerchief shown in high relief, with his palm rested horizontally on the thigh. ${ }^{47}$ The legs are more developed with the angular-edges knees, the bulging kneecaps, the stylized calves touching each other, the well sculpted and formed tibia and the two large parallel depressions running along the legs' external face.

When the king wears the nemes, the lappets are very far according to the very large neck. The pleats are standard with equal width, tailored with a frontlet and a coiled uraeus ending at the back of the nemes with a pointed tail. But when wearing the white crown, the hood of the uraeus springs at its lower edge and the frontlet is absent. Most of the statues show the king wearing the false beard. The royal costume is always the pleated $\check{s}$ dyt kilt, held by a plain belt engraved with a horizontal cartouche of the king but without the bull's tail. ${ }^{48}$

All the aforementioned characteristics and features are generally reserved to King Amenemhat I portrait. So, the dyad of Buto, portraying the king seated next to Goddess Wadjet (statue 1) (Pl. 1), could be dated to King Amenemhat I reign. Although the dyad bears King Ramses II name, the iconography and the facial characteristic are identical to the dating criteria ascribed to King Amenemhat I, whose physiognomy on this dyad similarly matches another seated statue of the king from Khatana (pl. 13). ${ }^{49}$

The dyads of the early Twelfth Dynasty ${ }^{(50)}$ are comparable to this dyad as it has the same features mentioned above: The low backrest with no back slab (a characteristic reserved to the Middle Kingdom

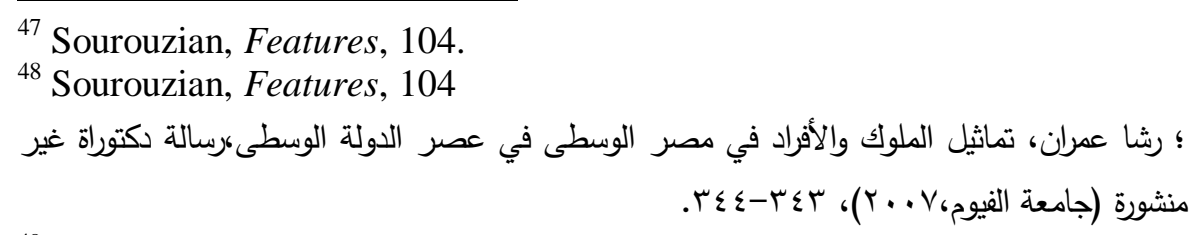

${ }^{49}$ Sourouzian, Features, pl. VI.

${ }^{50}$ Very few examples of Middle Kingdom seated dyads have survived, most of them are damaged either the lower part or the bust is preserved: The dyad of King Senousert I and Goddess Isis from Abydos (M. Seidel, "Die Könglichen Statuengruppen”, I, HÄB 42 (Hildeshaim, 1996), doc. 39, pl. 26 (b)); another dyad from Tod where the king is seated next to Goddess Sekhmet (F. Bisson de la Roque, "Tôd (1934 à 1936)", FIFAO 17 (Le Caire, 1937), fig. 59; Seidel, $H \ddot{A B}$ 42, doc. 34). 
dyads), the small structured ears, the full cheeks, the sunk relief ornamentation of the $s m 3 t 3 w y$ and the traditional narrow rectangular throne. Because of the absence of the bull's tail, this dyad could not be one of those of King Senousert I, which appeared on seated royal statues only under his reign. ${ }^{51}$

The arms' superposition is uncommon and unique. But unfortunately, the damage of the seated dyads of the twelfth Dynasty prevents us from determining the arms position of both figures. Usually, the king's palms are portrayed flat on his knees, with his right clenched grasping a kerchief and the goddess embracing the king with her right arm. Therefore, the mutual embracement in this dyad is a sign: The goddess puts her right arm in a slanted position on the king's back, while his left forearm embraces her waist laterally. ${ }^{52}$

The difference is obvious when comparing this dyad to those of King Ramses II. A dyad in the same temple at Buto represents the king and Goddess Sekhmet seated next to each other, she is represented lionheaded, surmounted by a sun-disk (Pl. 14). The physiognomy of the king is not the same as the dyad with Goddess Wadjet. The shape of the face is totally different, the shoulders are wider and the torso is shorter. Another important difference is the existence of the back slab. In addition, Goddess Wadjet is portrayed in the New Kingdom lion-headed, not as human-headed. All these reasons solidify the reasoning that the dyad could not be dated to King Ramses II reign. It is an original work of the Middle Kingdom. ${ }^{53}$

\section{StATUES AsCribed To KING SENOUSERT I}

The sculptors of King Senousert I adopted a new creative stylistic trend by correlating traditional conventions with original characteristic features. The different styles of his statues are due to the great number of his statuary that still exists in Delta, El-Lisht and Upper Egypt. ${ }^{54}$ The facial features of King Senousert I statues are characterized by: The rectangular face; the horizontal eyebrows drawn in relief; the closeness of the eyebrows and the eyes to the nose, with the eyes slightly oblique; the elongated inner canthi positioned lower than the outer ones; the full cheeks; the rounded protruding chin; the straight mouth and the full lips with two depressions at both ends, that give a stern firm expression. ${ }^{55}$

\footnotetext{
${ }^{51}$ Sourouzian, Features, 107.

${ }^{52}$ Sourouzian, Features, 107.

${ }_{53}$ Sourouzian, Features, pl. II A.

${ }^{54}$ Sourouzian, Features, 108.

${ }^{55}$ Sourouzian, MDAIK 44, 253.
} 
Additionally, the group statues are propped by a huge thick back slab. Two red granite group statues are ascribed to King Senousert I during this period: Koptos triad portraying the king seated between Goddesses Hathor and Isis (statue 2) (Pl. 2) and Memphis dyad representing the king seated next to God Ptah-Tatenen (statue 3) (Pl. 3). Although their inscriptions similarly state the name of King Ramses II, some characteristic features of King Senousert I are clearly obvious, specifically, the firm and stern expression of the face; the wide open eyes with protruding eyeballs; the heavy lower eyelids under which incurved hollow that gradually gives the way to the full cheeks; and the nemes straight stripes with its wings pushed back reaching the shoulders thickness, which is an exclusive characteristic of King Senousert I. The sculpting of the torso is totally different from that of the Ramesside statues and the tip of the king's breast are inlaid. Another characteristic mark is the large back-slab propping the groups. ${ }^{56}$

Some modifications have been carried out on the triad of Koptos (statue 2) (Pl. 2) to conform them to King Ramses II iconography: To fit the king forehead, a few millimeters from the front of the nemes were removed. Consequently, the stripes of the nemes, the uraeus and the frontlets were stripped. The ears were greatly and clumsily reduced and the ear-laps were pierced. A false beard was added and attached to the chin by a mortise, and the band attaching the beard is slightly carved with no traces of thickness.

Two folds were chiseled on the necks of the three figures. ${ }^{57} \mathrm{~A}$ hole was made on the top of each figure's head to put possibly a crown above the older ones, probably the double crown for the king and the distinctive emblems for Goddesses Isis and Hathor. An emblem is the solar disk between the two horns of the cow. This is because the two goddesses were named Isis and Hathor only during, and after the triad was reused by King Ramses II. Unfortunately, those emblems actually disappeared.

The faces have been retouched and re-polished to equalize the polish of the rest of the group. The Ramesside-type belt is roughly engraved and apparently redone. During the Middle Kingdom, the belts were simple ornamented, composing of squares divided by four vertical

\footnotetext{
${ }^{56}$ Sourouzian, MDAIK 44, 235, note 27; Vandersleyen, Chiefs of Seers, 286.

${ }^{57}$ Vandersleyen, Chiefs of Seers, 286; Sourouzian, Features, 109.
} 
lines, which is the same ornamentation as the two goddesses dress straps and the ribbons beneath their breasts. Those straps pass on the sides of the breasts, not on the breasts. ${ }^{58}$

\section{StATUes ASCRIBED To King SENOUSERT II}

King Senousert II reigned about seven years according to literature. It is extremely hard to attribute any statue to this king because of the absent of any inscribed preserved statue with its head intact. The statues of the king belong to the same artistic classic school. However, the reign of King Senousert II is highlighted by some noticeable alterations in facial features, style and attitude. The eyebrows are curved towards the nose, not anymore the traditional horizontal shape. The mouth is more natural with no false beard, consequently, the statues appear much more human. The palms are not anymore placed flat on the thighs as the right one holds a folded cloth while resting vertically on the thigh. ${ }^{59}$

Accordingly, the seated statue of Berlin (statue 4) (Pl. 4) can be ascribed to King Senousert II. ${ }^{(60)}$ Although it is completely engraved by King Ramses II and King Merenptah, it does not conform both kings artistic style. The re-carving process is apparent in the reshaped eyes, ears, mouth, nemes wings, in addition to the removal of the sides and lower edge of the uraeus hood. ${ }^{61}$ Parts of the original details have survived: The triple stripe of the nemes still apparent on the back of the nemes, the ornamentation of the uraeus, the eyebrows, the eyes shape and the cosmetic lines. Those details match the features of the Louvre sphinx, which allows attributing this statue to either King Amenemhat II or his son King Senousert II. ${ }^{62}$

The two seated statues (statue 5) (Pl. 5) and (statue 6) (Pl. 6) are presumed to be King Senousert II. After comparing them to two seated statues of Queen Nofret, the wife of King Senousert II (CG $381,382) .{ }^{(63)}$ In those two statues, the queen is portrayed with a round face and full cheeks, matching those of the king. The four

\footnotetext{
${ }^{58}$ Vandersleyen, Chiefs of Seers, 286-287.

${ }^{59}$ Vandier, Manuel, 181-182; Fay, The Louvre Sphinx, 59-60.

${ }^{60}$ Evers, Staat I, pl. 64; Sourouzian, Merenptah, 94-95, doc. 47; B. Fay, "A Re-used Bust of Amenemhat II in the Hermitage", GM 160 (Göttingen, 1996), pls. 75-77.

${ }^{61}$ Fay, The Louvre Sphinx, 59, pls. 76 a, c, 77 a.

${ }^{62}$ Fay, The Louvre Sphinx, 59, pls. 76 a-b-c, 77 b.

63 Borchard, Statuen II, 34-36, pl. 70; Evers, Staat I, pls. 67-68; Fay, The Louvre Sphinx, 60, pl. 79 a-b; Vandersleyen, Cheef of Seers, 287, note 2.
} 
statues were discovered at Tanis. Most probably, the queen statues have been paired with those of the king. Apparently, they are of Tanis style established during King Amenemhat II reign and then followed by his son King Senousert II, who tended to the naturalistic style, promoted by his son and successor King Senousert III. ${ }^{64}$ In both statues of the king, the face, the ears and the eyes have been modified to look like King Ramses II effigy. The original inscription has been entirely substituted by King Ramses II name and titles. ${ }^{65}$

The lower part of a seated royal statue was discovered in Bubastis (statue 7) (Pl. 7). Unluckily, it is hard to determine the exact date of the statuary, because the upper part is totally missing. Though, it could be ascribed to King Senousert II by comparing the decoration of the $s m 3$ t3wy engraved on the two sides of the throne with that of the two statues discussed above (statues 5, 6) (Pls. 5, 6). There, the scene portrays the two heraldic plants knotted together and held by the two Nile Gods Hapy. Those scenes are identical. The Bubastis statue does not have any marks of the original inscription; it is totally replaced with the name of King Ramses II. The inscriptions on the back pillar and on the statues of Tanis (statues 5, 6) (Pls. 5, 6) are the same, stating that the king is "The beloved of Rê-Horakhty and Amun-Rê".

The lower part of female royal statuary was discovered in Tanis (statue 8) (Pl. 8). The inscriptions of King Senousert II are on the front of the throne. While on its both sides and back, there is a long inscription bearing the name of Tuy, the mother of King Ramses II. The Ramesside inscriptions are clearly different from the highly delicate and polished hieroglyphs of the Twelfth Dynasty. The princess' titles on the front are repeated on the two sides as a part of the inscription of King Ramses II's mother. The statuary arguably belonged to one of the daughters of King Senousert II, and was later reprocessed during the reign of King Ramses II. The text of his mother Tuy replaced that of the princess.

\section{STATUES ASCRIBED TO KING SENOUSERT III}

The second half of the Twelfth Dynasty was recognized as a period of economic stability and internal peace, with long prosperous reigns of the kings. King Senousert III reign was the turning point in artistic, political and administrative development of the Middle Kingdom. He followed a new artistic innovation characterized by the intense

\footnotetext{
${ }^{64}$ Fay, The Louvre Sphinx, 60.

${ }^{65}$ Vandersleyen, Cheef of Seers, 287, note 2.
} 
realism in the royal sculpture representation. This trend has already begun by his father King Senousert II, reached its extreme during his reign. Although the sculptors retained the usual idealized royal physiognomy by leaving the body youthfully represented, they converted the faces into aged, bitter brooding and psychological images. ${ }^{66}$ Per the realistic school, the main mission of the artistic innovation is to demonstrate the king's awareness of his responsibilities and duties towards the state. This awareness is embodied by the harsh expression of the face, the tired eyes with heavy lids, the strong realistic wrinkles between the eyes, the enormous ears, the bitter mouth and the bulging chin. The body admirably reflects the strength, and power of a youthful conqueror. ${ }^{67}$

As a result, King Senousert III can be credited with three seated statues from Ehnasya: (statue 9) (Pl. 9) displayed now in University Museum, Philadelphia under number E $635,{ }^{68}$ (statue 10) (Pl. 10), (statue 11) (Pl. 11) displayed in the Egyptian Museum garden, under numbers JE 45975, JE $45976 .{ }^{69}$ Despite being completely engraved with King Ramses II names, those statutes are diverse from his known characteristics. Based on the fact that the three statues were discovered at the same site and the similarities between the colossus in Philadelphia and those in the Egyptian Museum, the researcher assigned the latter to King Senousert III reign.

On the Egyptian Museum statues, there are marks and signs from the original cartouches of King Senousert III; the reworking is quite apparent. On statue 11, King Merenptah inserted his own cartouche on the shoulders, the chest and the two sides of the throne.

On the colossus in University Museum, Philadelphia, the duplication of $\odot s 3-R^{c}$ above the second cartouche on the left side of the throne can be easily observed as both signs are in opposite directions (statue 9) (P1.9). According to the direction of the text, the $\odot$ should be facing right. This error is obviously from the re-carving, the facing left was covered with plaster so that the one facing right was only visible. Later after being transported to the museum, the plaster was lifted out and the re-carving was exposed (Fig. 8b). Ostensibly, it

\footnotetext{
${ }^{66}$ Fay, The Louvre Sphinx, 60; R. Freed, "Another Look at the Sculpture of Amenemhat III", RdE 53 (Paris, 2002), 103-104.

${ }^{67}$ Saleh and Sourouzian, The Egyptian Museum, n. 98.

${ }^{68} \mathrm{Ph}$. Miller, JEA 25, pls. 1-7, pls. I-III.

${ }^{69}$ Daressy, ASAE 17, 33-38; Sourouzian, Merenptah, 109-110, doc. 63.
} 
was the sculptor's mistake.

The two colossi of the Egyptian Museum are almost indistinguishable from the one in Philadelphia. They were all discovered at the ruined temple of King Ramses II at Kom El-Akareb, south of the temple of Harshaphes rebuilt by King Ramses II. King Ramses II reused ancient constructions including colossal statues from the Middle Kingdom. Accordingly, they have to be the original work of King Senousert III. King Merenptah later inserted his cartouche on one of the statues to sustain the cult renovated by his father. Finally, those two statues of the Egyptian Museum (Statues 10, 11) (Pls. 10, 11) were altered by adding the figurines of princesses Bentanat and Meritamun beside the legs of their father King Ramses II.

\section{COMMENTARY}

Identification of King Ramses II portrait is relatively straight forward based on the characteristics and criteria drawn from the well-dated monuments and statues. On the majority of his statues, the king wears a round wig or the nemes surmounted by the double crown, the double crown without any other coiffures, occasionally the blue crown or rarely the white crown with the frontal uraeus. The šndyt kilt is longer with more dense pleats than those worn during the Eighteenth Dynasty, its tab is broader and its buckle is cartoucheshaped. The bracelets and the collars are always in high relief. The front projection of the handkerchief and the container held in hands are either concave or flat and usually is inscribed with a cartouche bearing the king's name. ${ }^{70}$

His face is more triangular and occasionally sort of a compact round shape, particularly when wearing the round wig. The ears are small with pierced ear-laps. The upper eyelids are lowered as if the king is looking downward. The eyes are almond-shaped, with the inner canthi going slightly downwards. The mouth is curved with its corners drawn upwards in a slight smile. The torso is short and depicts a schematic sculpture: The arms are well engraved but vertical, the forearm's muscle is shallow and the wrist in most of the time is decorated by a bracelet. The legs are massive while the knees and the ankles are extremely thick. The knee-caps are round or have rounded corners and topped by a shallow reversed V-shaped muscles. Lastly, King Ramses II Statuary is always propped by narrow back

\footnotetext{
${ }^{70}$ Vandersleyen, Vallée 2, 234, 247- 248.
} 
pillars, round-topped or ending in the form of an obelisk. ${ }^{71}$

Based on contrasting the characteristics and criteria of King Ramses II statues with the above-mentioned analysis of the Middle Kingdom royal statues, it can be concluded that those aforementioned statues are in-fact not the original works of King Ramses II.

Most scholars and Egyptologists debated the act of reprocessing the statues, but most of them labeled this act as usurpation regardless of the motivations and reasons, whether for political or religious purposes, that made the king or others to reprocess a predecessor's statue.

Eaton-Krauss mentions that King Ramses II's reprocessing of Middle Kingdom works points to an antiquarian interest, reflecting his desire to revive the glories of the classical past. She adds that the trend toward historical awareness culminated during his reign. ${ }^{72}$

Sourouzian illustrated that process of re-inscribing and reprocessing of statues by King Ramses II was carried out in series or in groups, and then placed in temples that included his original statues. The latter groups were either copies from earlier work which completed the series, or supplementary items to the temple's furniture. Mostly, the act of usurpation is some kind of imitation. ${ }^{73}$

Vandersleyen illustrated that every seated colossus of King Ramses II has been suspected to be reused from the Middle Kingdom works, which is a subset of the numerous Middle Kingdom works that have been reused by the king. This could be a form of reincarnation into admirable ancestors ${ }^{74}$ rather than an act of vandalism or sacrilege.

Nur-Eldin stated that the victorious King Ramses II needed not to

${ }^{71}$ Borchardt, Statuen II, 162-163; Vandier, Manuel, 393-396, pl. CXXXV, 1; M. Eaton-Krauss, "The Statues of King Merenptah", in: Fragments of a Shattered Visage. The Proceedings of the International Symposium of Ramesses the Great (Tennessee, 1993) 15, 17; Vandersleyen, Vallée 2, 230, 235-236; P. Brand, The Monuments of Sethi I. Epigraphic, Historical and Art Analysis (Leiden, 2000), 139.

${ }^{72}$ M. Eaton-Krauss, Ramses-Re, 18-19.

${ }^{73}$ H. Sourouzian, "Les Colosses du IIe Pylône du Temple d'Amon-Rê à Karnak, Remplois Ramessides de la XVIIIe Dynastie", Cahiers de Karnak X (Le Caire, 1995), 505.

${ }^{74}$ C. Vandersleyen, "Sur Quelques Statues Usurpées par Ramsès II (British Museum 61 et Louvre A 20)", First International Congress of Egyptology (Berlin, 1979), 665; Vandersleyen, Chief of Seers, 665. 
usurp earlier monuments. But mostly as Nur-Eldin added, the inscriptions left by King Ramses II on the reprocessed monuments were some kind of restoration and glorification. It was normal, when a king added or modified or restored a monument, to be entitled to inscribe his name on it as a record for his achievements. ${ }^{(75)}$

The researcher subscribes to the opinion, illustrated by Nur-Eldin, that a glorious and an accomplished king like Ramses II needed not to usurp his ancestors' monuments. In the Eighteenth and Nineteenth Dynasties, Egypt was a great empire ruled by powerful kings. The political standing was well established, and its economy was prosperous. Accordingly, the king did not reprocess older monuments and statues due to lack of materials. But most probably, it was looked upon as maintaining and restoration of his ancestors' heritage.

Table 1 Representing Middle Kingdom Seated Royal Statues Reused by King Ramses II

(Documents are arranged according to chronological order)

\begin{tabular}{|c|c|c|c|c|}
\hline $\begin{array}{c}\text { Statue } \\
\text { Number/Current } \\
\text { Location }\end{array}$ & Provenance & Material & Dating & Description \\
\hline Statue 1 , in situ & $\begin{array}{c}\text { Buto, temple } \\
\text { of Goddess } \\
\text { Wadjet }\end{array}$ & $\begin{array}{c}\text { Red } \\
\text { granite }\end{array}$ & $\begin{array}{c}\text { Dynasty } \\
\text { XII, reign of } \\
\text { King } \\
\text { Amenemhat } \\
\text { I }\end{array}$ & $\begin{array}{l}\text { A dyad } \\
\text { representing } \\
\text { the king } \\
\text { seated next } \\
\text { probably to } \\
\text { Goddess } \\
\text { Wadjet }\end{array}$ \\
\hline $\begin{array}{c}\text { Statue 2, } \\
\text { Egyptian } \\
\text { Museum, Cairo, } \\
\text { CG 555 }\end{array}$ & Koptos & $\begin{array}{l}\text { Dark- } \\
\text { brown red } \\
\text { granite }\end{array}$ & $\begin{array}{l}\text { Dynasty } \\
\text { XII, reign of } \\
\text { King } \\
\text { Senousert I }\end{array}$ & $\begin{array}{l}\text { A triad } \\
\text { representing } \\
\text { the king } \\
\text { seated } \\
\text { between } \\
\text { Goddesses } \\
\text { Isis and } \\
\text { Hathor }\end{array}$ \\
\hline $\begin{array}{c}\text { Statue 3, } \\
\text { Egyptian } \\
\text { Museum, Cairo, }\end{array}$ & Memphis & $\begin{array}{l}\text { Dark-red } \\
\text { granite }\end{array}$ & $\begin{array}{l}\text { Dynasty } \\
\text { XII, reign of } \\
\text { King }\end{array}$ & $\begin{array}{l}\text { A dyad } \\
\text { representing } \\
\text { the king }\end{array}$ \\
\hline
\end{tabular}

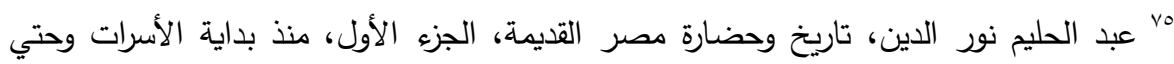

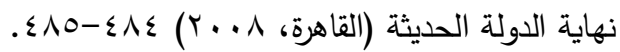




\begin{tabular}{|c|c|c|c|c|}
\hline CG 554 & & & Senousert I & $\begin{array}{l}\text { seated next to } \\
\text { God Ptah- } \\
\text { Tatenen }\end{array}$ \\
\hline $\begin{array}{l}\text { Statue 4, Berlin } \\
\text { Museum, no. } \\
7264\end{array}$ & Tanis & $\begin{array}{l}\text { Grey } \\
\text { granite }\end{array}$ & $\begin{array}{c}\text { Dynasty } \\
\text { XII, reign of } \\
\text { King } \\
\text { Senousert II }\end{array}$ & $\begin{array}{l}\text { A seated } \\
\text { statue } \\
\text { depicting the } \\
\text { king seated } \\
\text { on a cubic } \\
\text { throne, } \\
\text { wearing the } \\
\text { nemes } \\
\text { headdress }\end{array}$ \\
\hline $\begin{array}{c}\text { Statues 5-6, } \\
\text { Egyptian } \\
\text { Museum, Cairo, } \\
\text { CG 430, CG } 432\end{array}$ & Tanis & $\begin{array}{l}\text { Black } \\
\text { granite }\end{array}$ & $\begin{array}{c}\text { Dynasty } \\
\text { XII, reign of } \\
\text { King } \\
\text { Senousert II }\end{array}$ & $\begin{array}{l}\text { Two seated } \\
\text { statues } \\
\text { almost } \\
\text { similar to } \\
\text { statue } 4 \\
\end{array}$ \\
\hline $\begin{array}{l}\text { Statue 7, the head } \\
\text { is in Sydney } \\
\text { Museum, } \\
\text { Australia; the } \\
\text { lower part is left } \\
\text { in situ }\end{array}$ & Bubastis & $\begin{array}{l}\text { Black } \\
\text { granite }\end{array}$ & $\begin{array}{c}\text { Dynasty } \\
\text { XII, reign of } \\
\text { King } \\
\text { Senousert II }\end{array}$ & $\begin{array}{l}\text { The lower } \\
\text { part of a } \\
\text { seated statue, } \\
\text { the head is } \\
\text { covered by } \\
\text { the white } \\
\text { crown }\end{array}$ \\
\hline $\begin{array}{c}\text { Statue 8, } \\
\text { Egyptian } \\
\text { Museum, Cairo, } \\
\text { no. } 99\end{array}$ & Tanis & $\begin{array}{l}\text { Black } \\
\text { granite }\end{array}$ & $\begin{array}{c}\text { Dynasty } \\
\text { XII, reign of } \\
\text { King } \\
\text { Senousert II }\end{array}$ & $\begin{array}{c}\text { The lower } \\
\text { part of a } \\
\text { female seated } \\
\text { statue } \\
\text { inscribed } \\
\text { with the } \\
\text { name of Tuy, } \\
\text { the mother of } \\
\text { King Ramses } \\
\text { II }\end{array}$ \\
\hline $\begin{array}{c}\text { Statue 9, } \\
\text { University } \\
\text { Museum, } \\
\text { Philadelphia, E } \\
635\end{array}$ & Ehnasya & $\begin{array}{l}\text { Unpolished } \\
\text { light } \\
\text { yellow } \\
\text { quartzite }\end{array}$ & $\begin{array}{c}\text { Dynasty } \\
\text { XII, reign of } \\
\text { King } \\
\text { Senousert } \\
\text { III }\end{array}$ & $\begin{array}{c}\text { A seated statue } \\
\text { representing } \\
\text { the king seated } \\
\text { on his throne, } \\
\text { wearing the } \\
\text { nemes } \\
\text { headdress }\end{array}$ \\
\hline $\begin{array}{l}\text { Statues 10-11, } \\
\text { Egyptian } \\
\text { Museum, Cairo, }\end{array}$ & $\begin{array}{l}\text { Ehnasya at } \\
\text { Kom El- } \\
\text { Akareb, south }\end{array}$ & $\begin{array}{l}\text { Unpolished } \\
\text { yellow } \\
\text { quartzite }\end{array}$ & $\begin{array}{l}\text { Dynasty } \\
\text { XII, reign of } \\
\text { King }\end{array}$ & $\begin{array}{l}\text { Two seated } \\
\text { statues } \\
\text { similar to }\end{array}$ \\
\hline
\end{tabular}




\begin{tabular}{|c|c|c|c|}
\hline JE 45975, JE & $\begin{array}{c}\text { of Harshaphes } \\
\text { temple, in the } \\
\text { destroyed } \\
\text { temple of }\end{array}$ & & Statue 9 \\
King Ramses & & & \\
II & & & \\
\hline
\end{tabular}

\section{CONCLUSION}

- Elven seated royal statues that go back to the Middle Kingdom were reused by King Ramses II.

- From all the seated royal statues of King Ramses II reused from the Middle Kingdom, only two are group statues (statues 1 and 2) (Pls. 1, 2). This is maybe because most of the royal Middle Kingdom group statues are damaged, which made the reuse and the restoration difficult, or because they were widely reused during the Ramesside period before King Ramses II reign.

- Statue 1 (Pl. 1), representing originally King Amenemhat I and Goddess Wadjet, is considered to be the oldest reused dyad from the Middle Kingdom.

- Statue 2 (Pl. 2), portraying originally King Senousert I seated between Goddesses Isis and Hathor, is considered to be the oldest reused triad from the Middle Kingdom.

- The statues of King Ramses II reused from the Middle Kingdom are characterized by the colossal size.

- No reused seated royal statues go back originally to the Eleventh Dynasty.

- Most of the seated royal statues were reused from Kings Senousert II and Senousert III statues.

- Most of the reused seated royal statues of the Middle Kingdom are made of granite (8 statues) and only 3 are made of quartzite.

- Most of the reused statues were found at Tanis, Memphis and Bubastis which indicate that King Ramses II reused elaborate monuments at prominent sites.

- The last seated royal statues reused by Ramses II from the Middle Kingdom are the two identical statues displayed in the Egyptian Museum garden under numbers JE 45975 and JE 45976.

- In most cases, the inscriptions of the original owner of the 
statue were totally erased and replaced by new text comprising the name and titles of King Ramses II, and sometimes with adding new inscriptions. Usually, the difference between the technique and the polish of the re-inscribed area and the original one makes it easy to identify the reused work.

- Sometimes, the inscriptions of King Ramses II were engraved on areas that were not inscribed for the original owner. In other cases, beside the replacement of the inscriptions, some changes had to be made to resemble the effigy of King Ramses II.

\section{REFERENCES}

Aldred, C., "Some Royal Portraits of the Middle Kingdom in Ancient Egypt", MMJ 3 (New York, 1970), 27-50.

Aldred, C., Egyptian Art in the Days of the Pharaohs (London, 1985). Bisson de la Roque, F., "Tôd (1934 à 1936)", FIFAO 17 (Le Caire, 1937).

Borchardt, L., Statuen und Statuetten von Königen und Privatleuten Catalogue Général des Antiquités Egyptiennes du Caire 4, col. 2 (Berlin, 1925).

Brand, P., The Monuments of Sethi I. Epigraphic, Historical and Art Analysis (Leiden, 2000).

Daressy, G., "Deux Grandes Statues de Ramsès II d'Hérakléopolis", ASAE 17 (Le Caire, 1917), 33-38.

Eaton-Krauss, M., "Ramesses-Re Who Creates the Gods", in: Fragments of a Shattered Visage: The Proceedings of the International Symposium of Ramesses the Great (Memphis State University-Tennessee, 1993), 15-23.

Eaton-Krauss, M., "The Statues of King Merenptah", in: Fragments of a Shattered Visage. The Proceedings of the International Symposium of Ramesses the Great (Memphis State UniversityTennessee, 1993), 226-249.

El Mekkawi, F., "Recent Excavations at Tell el Fara", DE, Special Number 1 (Cairo, 1989).

El-Shahawy, A., The Ancient Egyptian Museum in Cairo. A Walk through the Alleys of Ancient Egypt (Cairo, 2005).

Evers, H., Staat aus dem Stein I-II (München, 1929).

Fay, B., "A Re-used Bust of Amenemhat II in the Hermitage", GM 160, (Göttingen, 1996), 51-52.

Fay, B., The Louvre Sphinx and Royal Sculpture from the Reign of Amenemhat II (Mainz, 1996). 
Fischer, G., "The Mark of a Second Hand on Ancient Egyptian Antiquities", MMJ 9 (New York, 1974), 5-34.

Freed, R., "Another Look at the Sculpture of Amenemhat III", RdE 53 (Paris, 2002), 103-135.

Gauthier, H., Une Nouvelle Statue d'Amenemhat 1er". Mélanges Maspero I, MIFAO LXVI (Le Caire, 1935).

Hayes, W., "Royal Portraits of the Twelfth Dynasty", BMMA 5 (New York, 1946-1947), 119-124.

Kitchen, K., Ramesside Inscriptions II (Oxford, 1999).

Kitchen, K., Ramesside Inscriptions IV (Oxford, 1982).

Lacovara P. and Reeves N., "The Colossal Statue of Mycerinus Reconsidered", RdE 38 (Paris-1987), 111-115.

Mariette, A., in Recueil de Travaux Relatifs à la Philologie et l'Archéologie Egyptiennes et Assyriennes (Le Caire, 1887).

Maspero, G. and Brugsch, M. E., La Trouvaille de Deir el-Bahari (Le Caire, 1881).

Miller, Ph., "A Statue of Ramses II in the University Museum, Philadelphia", JEA 25, I (London, 1939), 1-7.

Mokhtar, M.G., "Ihnâsya el Medina (Herakleopolis Magna)", BdE 40 (Cairo, 1983).

Montet, P., Les Nouvelles Fouilles de Tanis (1929-1932) (Paris, 1932).

Naville, E., Ahnas el Medineh (London, 1894).

Naville, E., Bubastis (London, 1891).

Noblecourt, C.D., La Femme au Temps des Pharaons (Paris, 1985).

Petrie, F., Koptos (London, 1896).

Petrie, W. F., Ehnasya (London, 1905).

Petrie, W.F., A History of Egypt I (London, 1923).

Petrie, W.F., Tanis I (London, 1885).

Petrie, W.F., Tanis II. Nebesheh and Defeneh (London, 1888).

Porter, B., Moss, R., Topographical Bibliography of Ancient Egyptian Hieroglyphic Texts, Reliefs and Paintings III-V (Oxford, 1932-1937).

Saleh, M. and Sourouzian, H., The Egyptian Museum Cairo. Official Catalogue (Mainz, 1987).

Seidel, M., Die Könglichen Statuengruppen I, HÄB 42 (Hildeshaim, 1996).

Sourouzian, H., "A Headless Sphinx of Sesostris II from Heliopolis in the Egyptian Museum, Cairo. JE 37796", Studies in Honor of William Kelly Simpson II (Boston 1996), 743-754. 
Sourouzian, H., "Features of Early Twelfth Dynasty Royal Sculpture", Bulletin of the Egyptian Museum 2 (Cairo, 2005), 103-111.

Sourouzian, H., "Les Colosses du IIe Pylône du Temple d'Amon-Rê

à Karnak, Remplois Ramessides de la XVIIIe Dynastie", Cahiers de Karnak X (Le Caire, 1995), 505-529.

Sourouzian, H., "Les Monuments du Roi Merenptah", SDAIK 22 (Mainz, 1989).

Sourouzian, H., "Seth Fils de Nout et Seth d'Avaris dans la Statuaire

Royale Ramesside", in: Timelines: Studies in Honour of

Manfred Bietak (Leuven, 2006), 331-354.

Sourouzian, H., "Standing Royal Colossi of the Middle Kingdom

Reused by Ramses II", MDAIK 44 (Kairo-Berlin, 1988), 229254.

Sourouzian, S., The Egyptian Museum Cairo. Official Catalogue (Mainz, 1987).

Vandersleyen, C., "Ramsès II Admirait Sésostris I", Chief of Seers.

Egyptian Studies in Memory of Cyril Aldred (London, 1997), 285-289.

Vandersleyen, C., "Sur Quelques Statues Usurpées par Ramsès II (British Museum 61 et Louvre A 20)", First International Congress of Egyptology (Berlin, 1979).

Vandersleyen, C., L'Egypte et la Vallée du Nil 2 (Paris, 1995).

Vandier, J. "Iousâas et (Hathor) Nébet Hétépet", RdE 16 (Paris1964), 55-146.

Vandier, J., Manuel d'Archéologie Egyptienne, III. Les Grandes Epoques. La Statuaire (Paris, 1958).

$$
\begin{aligned}
& \text { رشا عمران (Y.V.V) تماثيل المولك والأفراد في مصر الوسطى في عصر الدولة الوسطى، } \\
& \text { رسالة دكتوراة غير منشورة، كلية السياحة والفنادق، جامعة الفيوم. }
\end{aligned}
$$

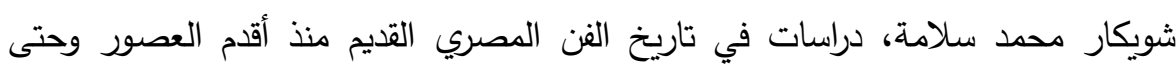

$$
\begin{aligned}
& \text { نهاية العصر المتوسط الثالث، الاسكندرية. }
\end{aligned}
$$

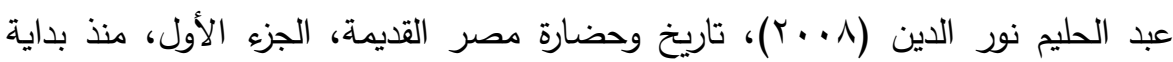

$$
\begin{aligned}
& \text { الأسرات وحتي نهاية الدولة الحديثة، القاهرة. }
\end{aligned}
$$

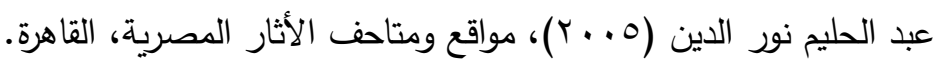

\section{INTERNET SITES}

www.museum.upenn.edu last accessed (15/6/2018) 7.00 pm. 


\section{FIGURES}

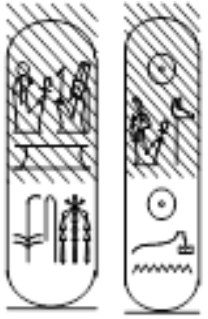

Figure 1

Inscriptions from statue 1

$\begin{array}{llllll}4 & 5 & 6 & 3 & 2 & 1\end{array}$

$10+\infty 8250$

14:

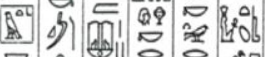

嬅

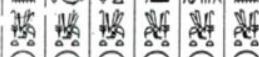

(0) (0) 000

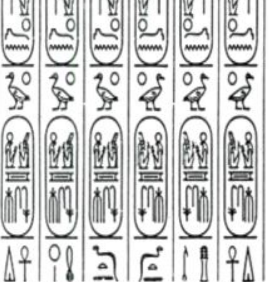

Figure $2 \mathrm{a}$

Inscriptions from statue 2

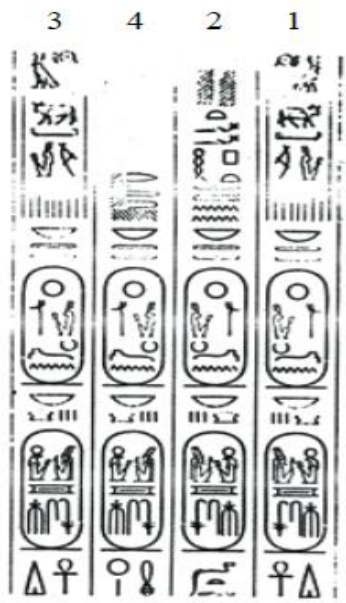

Figure 3

Inscriptions from Statue 3
3

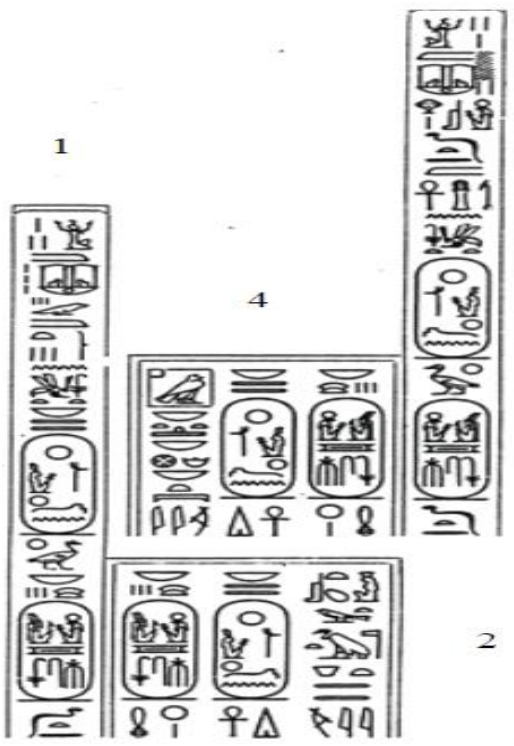

Figure $2 b$

Inscriptions from statue 2

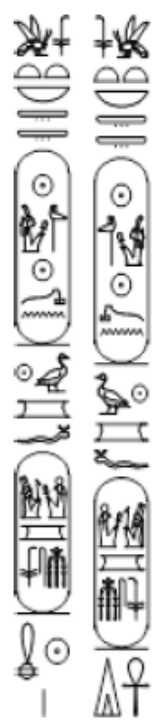

Figure 4

Inscriptions from statue 4 


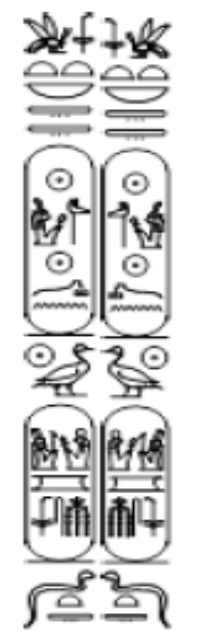

Figure 5a

Inscriptions from statue 5

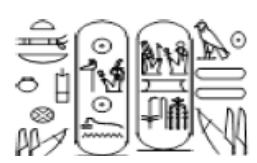

Figure 5b

Inscriptions from statue 5

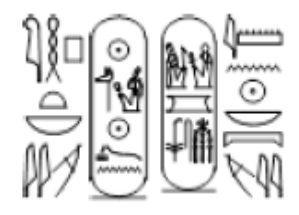

Figure 5c Inscriptions from statue 5

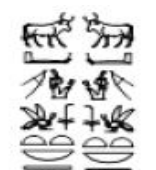

$\overline{\bar{D}}$

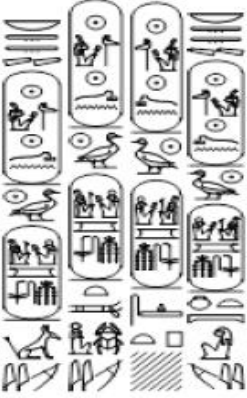

Figure 5d

Inscriptions from statue 5

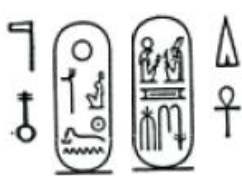

Figure 6a Inscriptions from statue 6

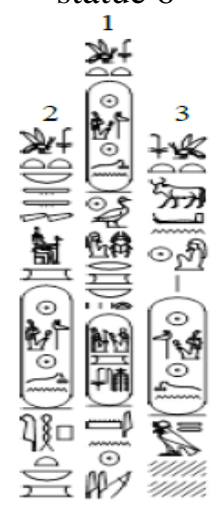

Fig 6b

Inscriptions from statue 6

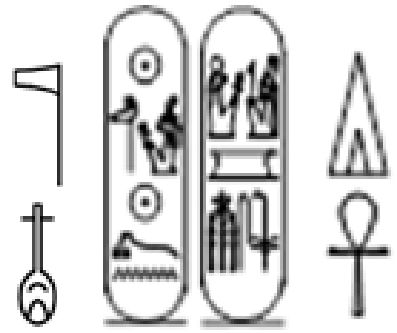

Figure 7

Inscriptions from statue 7

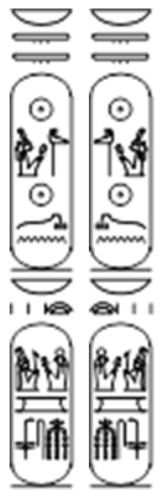

Figure8a Inscriptions from statue 9

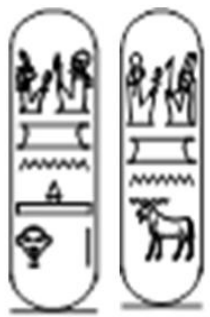

Figure 10a

Inscriptions from statue 11

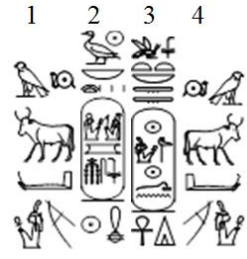

Figure 9b

Figure $9 \mathrm{a}$
Inscriptions from statue 10
Inscriptions from statue 10

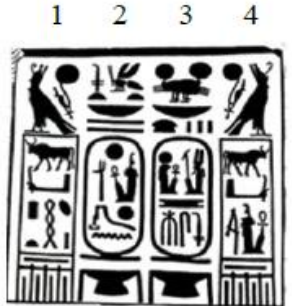

Fig $8 b$

Inscriptions from statue 9

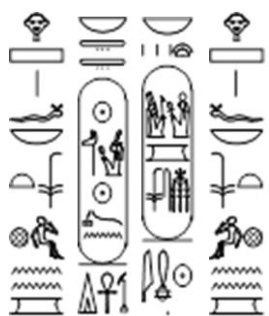

Figure 10b Inscrptions from statue 11 


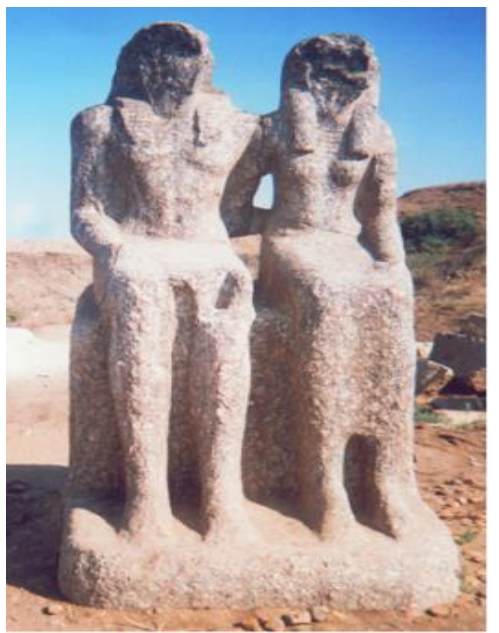

Plate 1: A dyad representing a king seated beside probably Goddess Wadjet

H. Sourouzian, "Features of Early Twelfth Dynasty Royal Sculpture", pl. VI a-b.

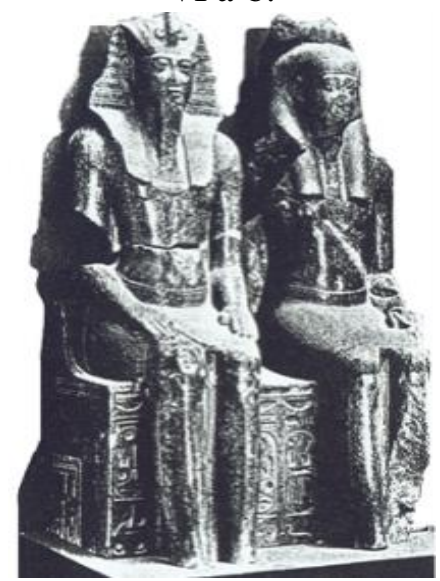

Plate 3: A dyad representing a king seated beside God Ptah-Tatenen

L. Borchardt, Statuen und Statuetten Königen und Privatleuten Catalogue Général des Antiquités Egyptiennes du Caire, II (Berlin, 1925), pl. 93.

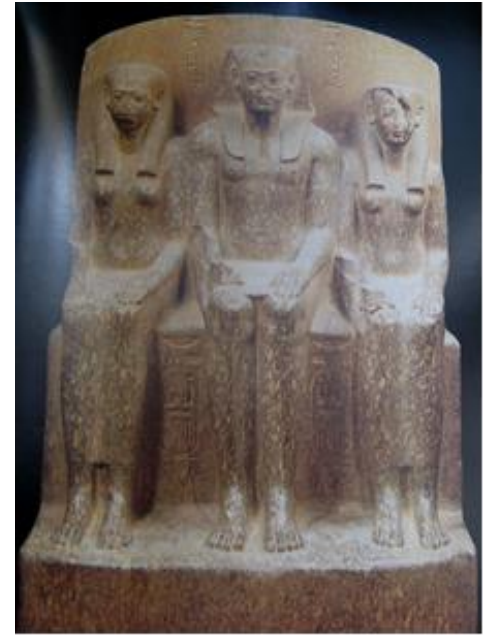

Plate 2: A triad representing a king seated between Goddesses Isis and Hathor

C.D. Noblecourt, La Femme au Temps des Pharaons (Paris, 1985), n. 80.

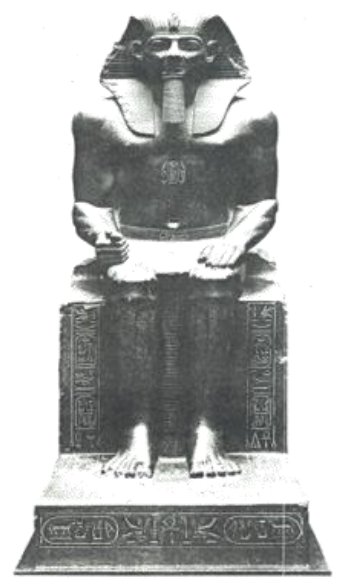

Plate 4: A seated royal colossus from Tanis

H. Evers, Staat aus dem Stein, I (München, 1929), pl. 64. 


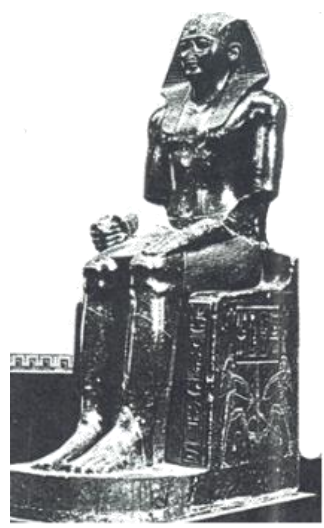

Plate 5: A seated colossus from Tanis Borchardt, Statuen II, pl. 70.

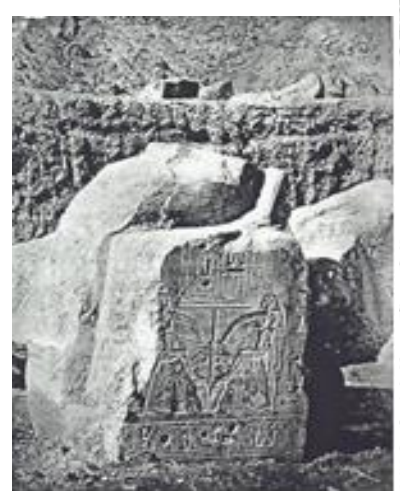

Plate 7: The lower part of seated royal colossus from Bubastis

E. Naville, Bubastis (London, 1891), pls . XXV(c), XXXVIII (a), pl. XIV (1).

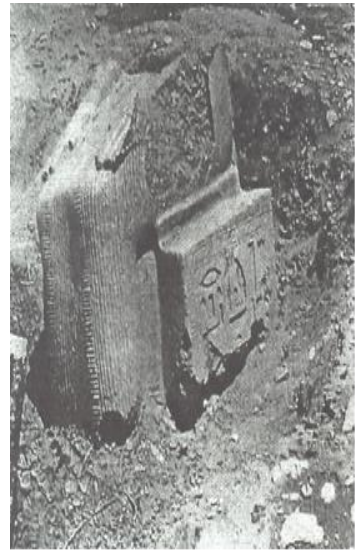

Plate 8: The lower part of a female seated statue inscribed with the name of Tuy

W.F. Petrie, Tanis, I (London, 1885), 67, pl. XIV (1).

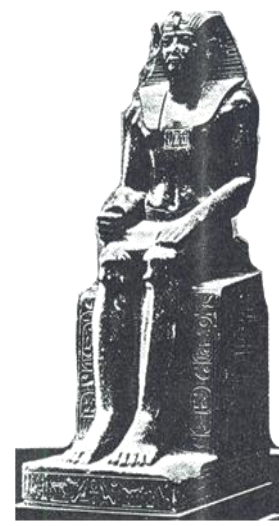

Plate 6: A seated royal colossus from Tanis

Borchardt, Statuen II, pl. 71.
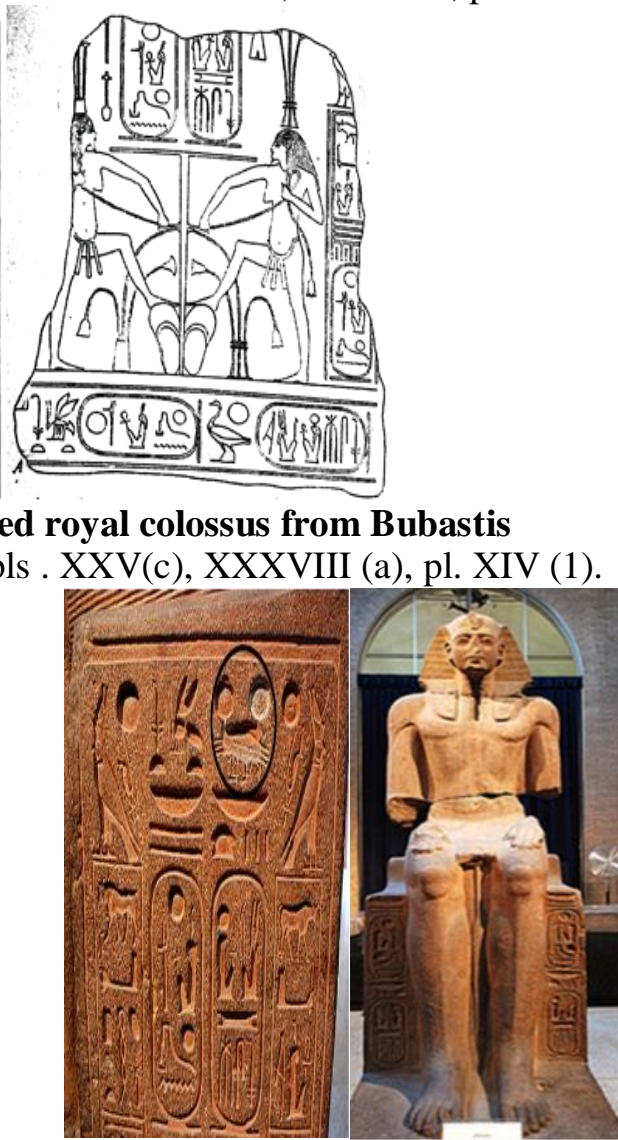

Plate 9: A seated royal Colossus from Ehnasya

www.museum.upenn.edu Last accessed 15/7/2018 7.00 pm 


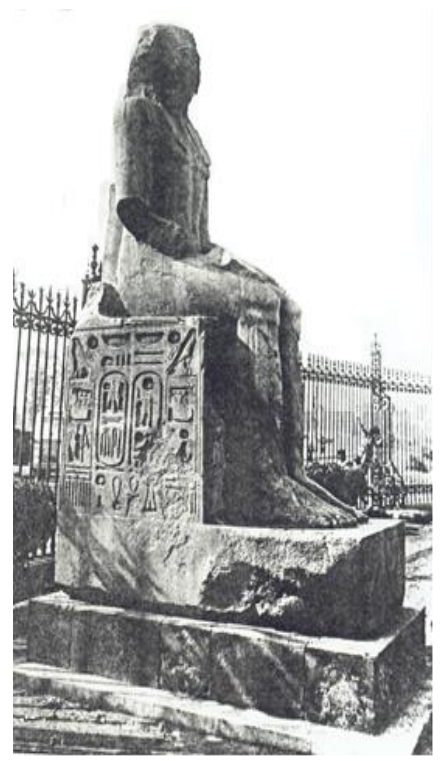

Plate 10: A seated royal colossus from Ehnasya

After Evers, Staat II, pl. XI (71).
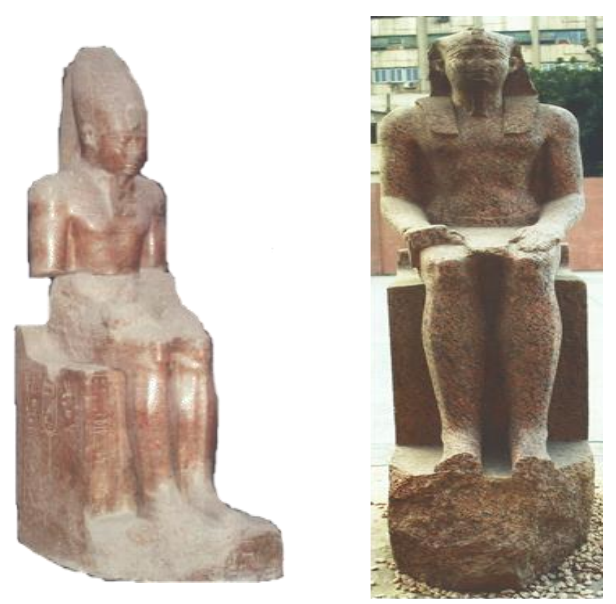

Plate 12: A seated royal colossus originally of Amenemhat I usurped by Merenptah Evers, Staat I, pl. 15.

Plate 13: A seated statue of Amenemhat I from Khatana. Sourouzian, Features, pl. II a.

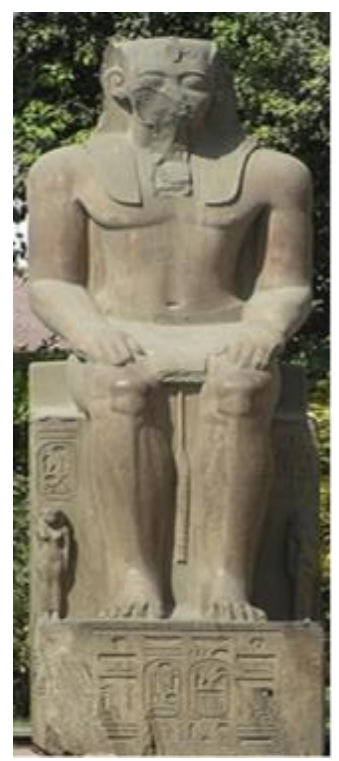

Plate 11: A Seated royal colossus from Ehnasya

After Evers, Staat II, pls. XVI (70).

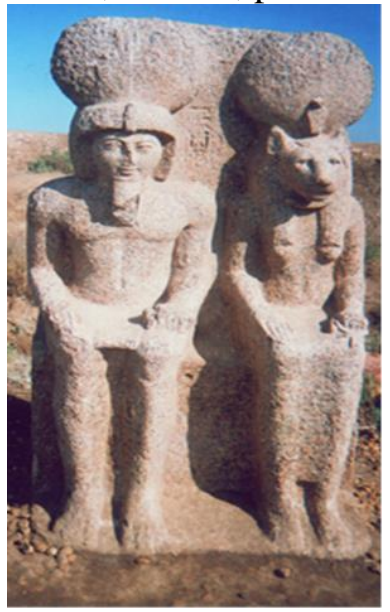

Plate 14: A seated dyad of Ramses II and Sekhmet from Buto Sourouzian, Features, pl. VI. 